
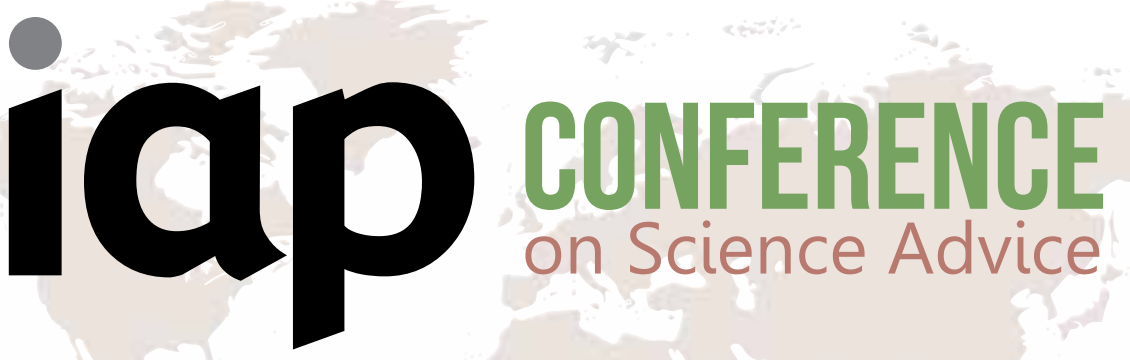

the interacademy partnership

\title{
Proceedings of the InterAcademy Partnership (IAP) Conference on Science Advice
}

28 February - 1 March 2016 Hermanus, South Africa 
(C) Academy of Science of South Africa

April 2016

ISBN 978-0-9946852-9-2

DOI http://dx.doi.org/10.17159/assaf.2016/0005

Published by:

Academy of Science of South Africa (ASSAf)

PO Box 72135, Lynnwood Ridge, Pretoria, South Africa, 0040

Tel: +27 123496600 • Fax: +27865769520

E-mail: admin@assaf.org.za

Reproduction is permitted, provided the source and publisher are appropriately acknowledged.

The Academy of Science of South Africa (ASSAf) was inaugurated in May 1996. It was formed in response to the need for an Academy of Science consonant with the dawn of democracy in South Africa: activist in its mission of using science and scholarship for the benefit of society, with a mandate encompassing all scholarly disciplines that use an open-minded and evidence-based approach to build knowledge. ASSAf thus adopted in its name the term 'science' in the singular as reflecting a common way of enquiring rather than an aggregation of different disciplines. Its Members are elected on the basis of a combination of two principal criteria, academic excellence and significant contributions to society.

The Parliament of South Africa passed the Academy of Science of South Africa Act (Act 67 of 2001), which came into force on 15 May 2002. This made ASSAf the only academy of science in South Africa officially recognised by government and representing the country in the international community of science academies and elsewhere.

This report reflects the proceedings of the InterAcademy Partnership (IAP) Conference on Science Advice held from 28 February - 1 March 2016. Hermanus, South Africa.

Views expressed are those of the individuals and not necessarily those of the Academy nor a consensus view of the Academy based on an in-depth evidence-based study. 


\section{Table of Contents}

Acronyms

CONFERENCE DAY ONE - 29 February 2016

1 OPENING SESSION

1.1 Opening and Welcome Remarks: Prof Daya Reddy 5

1.2 Keynote Speaker: Prof Sir Peter Gluckman

1.3 Keynote Speaker: Prof Jos van der Meer

1.4 Discussion

2 PANEL DISCUSSION:

Topic 1 - Science Advice Ecosystem

2.1 Dr Flavia Schlegel

2.2 Prof Howard Alper

2.3 Dr Khotso Mokhele

2.4 Prof Thomas Zeltner

2.5 Dr Tolu Oni

2.6 Discussion

3 PANEL DISCUSSION:

Topic 2 - Science Advice in Times of Disasters/ Emergencies

23

3.1 Prof Oyewale Tomori

3.2 Prof Coleen Vogel

3.3 Prof Ram Babu Singh

3.4 Prof Bernard Slippers

26

3.5 Prof Virginia Murray

28

3.6 Discussion

28

3.7 Closing Remarks

4 PANEL DISCUSSION:

Topic 3 - Science Advice in the International Arena with a Special Focus on Synthetic Biology

4.1 Prof Francisco Gonzalo Bolivar-Zapata

4.2 Prof Ernst-Ludwig Winnacker

4.3 Prof Rees Kassen 
4.4 Prof Keymanthri Moodley 33

4.5 Discussion 33

5 WRAP-UP SESSION 35

CONFERENCE DAY TWO - 1 March 2016

6 PANEL DISCUSSION:

Topic 4 - Country Readiness for Science Advice 36

6.1 Dr Orakanoke Phanraksa 36

6.2 Prof Mahouton Norbert Hounkonnou 38

6.3 Prof Kurt Lambeck 40

6.4 Dr Margaret Hamburg 43

6.5 Discussion 46

7 KEYNOTE SPEAKER:

Prof Jacqueline McGlade

\begin{tabular}{l|l}
7.1 Discussion & 56
\end{tabular}

8 PANEL DISCUSSION:

Topic 5 - Interplay between Science Advice, Politics and the Media

8.1 Ms Linda Nordling $\quad 60$

8.2 Mr David Mair 61

8.3 Prof Charles Weijer $\quad 62$

8.4 Prof Sameh Soror 63

8.5 Prof Bruce Alberts 64

$\begin{array}{ll}8.6 & \text { Discussion } \\ \end{array}$

9 PLENARY DISCUSSION, CONCLUSIONS, $\begin{array}{ll}\text { RECOMMENDATIONS } & \mathbf{7 0}\end{array}$

$\begin{array}{lll}9.1 & \text { Day } 1 \text { Wrap-up } & 70\end{array}$

$\begin{array}{lll}9.2 & \text { Day } 2 \text { Wrap-up } & 75\end{array}$

9.3 Questions and Comments 78

9.4 Closing: Prof Daya Reddy and Prof Jörg Hacker 80

10 PARTICIPANT LIST $\quad 82$ 


\section{Acronyms}

AAAS

AE

AIDS

ALLEA

ARV

ASSAf

DIY

EASAC

ENSO

EU

FEAM

GDP

GMO

GYA

HIV

IAC

IAMP

IANAS

IAP

ICSU

IECC

INGSA

IPCC

MDG
American Association for the Advancement of

Science

Academia Europaea

Acquired immunodeficiency syndrome

All European Academies

Antiretrovirals

Academy of Science of South Africa

Do it yourself

European Academies Science Advisory Council

El Niño Southern Oscillation

European Union

Federation for Academies of Medicine

Gross domestic product

Genetically modified organism

Global Young Academy

Human immunodeficiency virus

InterAcademy Council

InterAcademy Medical Panel

Inter-American Network of Academies of Sciences

InterAcademy Partnership

International Council for Science

International Energy Conservation Codes

International Network for Government

Science Advice

Intergovernmental Panel on Climate Change

Millennium development goal 
NGO

S\&T

SAPEA

SAYAS

SDG

SDGIO

STAG

STI

STIC

UK

UN

UNDP

UNEP

UNESCO

US NAS

WEHAB

WHO
Non-governmental organisation

Science and technology

Science Advice for Policy by European Academies South African Young Academy of Science

Sustainable development goal

SDG interface ontology

Scientific and Technical Advisory Group

Science, technology and innovation

Science, Technology and Innovation Council

United Kingdom

United Nations

United Nations Development Programme

United Nations Environment Programme

United Nations Educational, Scientific and

Cultural Organisation

US National Academy of Sciences

Water, energy, health, agriculture and biodiversity

World Health Organisation 


\section{Conference Day One - 29 February 2016}

\section{Opening Session}

\subsection{Opening and Welcome Remarks: Prof Daya Reddy (President of the Academy of Science of South Africa)}

Prof Reddy welcomed participants to the InterAcademy Partnership (IAP) Conference on Science Advice. He stated that the scientific community needs to play a direct role in ensuring that the scientific perspective is present in policymaking across various areas, such as climate change, urbanisation, disasters, deadly viruses, or emergencies that confront society. Scientists have a huge responsibility to ensure that scientific debates are informed by solid scientific evidence, logical argument, reasoning and sound advice.

Prof Reddy said science advice can be viewed as a component or subset of science diplomacy, which means that it would be the responsibility of scientists to use science to build bridges across divides, between individuals, and between organisations across national boundaries to create fora for greater insight, analysis and action. He noted that the organisers of the IAP conference have been overwhelmed with the interest shown in the theme of this meeting.

He said the science advice ecosystem is not a simple concept. Questions arise, such as who provides advice, under which circumstances, to whom and on what? While it is recognised that academies are not the exclusive custodians of science advice, they are an important component in the spectrum of individuals and organisations that provide advice.

He thanked the secretariats of the IAP and the Academy of Science of South Africa (ASSAf) for their roles in organising the conference. He further acknowledged the National Research Foundation and the Department of Science and Technology for funding the event. 


\subsection{Keynote Speaker: Prof Sir Peter Gluckman}

(Chief Science Advisor to the Prime Minister of New Zealand and Chair, International Network for Government Science Advice (INGSA))

Prof Gluckman said science does not stand apart from society. He added that as scientists we cannot separate the three circles of science, policy and society. With each of these changing rapidly, the interactions between them change as well. Science is clearly being seen as a tool of both national and international development. This is causing many governments to realise that science does have a useful role to play in policymaking.

In the context of government, science has moved from normal issues to post-normal issues. Prof Gluckman said the nature of science was changing, and over the past 30 to 40 years, it has moved from linear and reductionist approaches to accepting complexity, to dealing with systems-based approaches; and from certainty to probabilistic approaches.

\section{Post-normal science}

Prof Gluckman told participants that post-normal science is a term that was developed about 25 years ago as an application of science in a scenario where the science is complex, the facts are uncertain or incomplete, and there is much which is unknown. The stakes are often high, decision-making is urgent, and there is a high values component and the values are often in dispute. He said post-normal science is at the heart of where governments rely on science in policymaking. This ranges from environmental issues, policy issues, urbanisation, to ageing populations, etc.

\section{Skepticism about science}

Prof Gluckman said there are instances where post-normal science will clash with cognitive biases and core beliefs, and unless scientific evidence engages with disputed societal values, it will not be effective. He stated that this causes scepticism on many issues, including a long-running belief, for example, that 
Wifi causes brain tumours, amongst others. He also said science alone cannot resolve different world views, including views that genetically modified organisms (GMOs) are dangerous.

\section{Science and policymaking}

Policy is rarely determined by science alone, but policy can be informed by evidence. Prof Gluckman told delegates that there were various components that are labelled as inputs to policy. These include science, public opinion, political ideology, electoral contract, fiscal objectives and obligations, and diplomatic issues and any international obligations. While all of these values play a part in the policymaking process, robust scientific evidence is needed for the advice to be effective.

He gave an example of when he was appointed as Chief Science Advisor for New Zealand, when the government at the time decided to outlaw the inclusion of folic acid in bread as it was said to cause cancer. Despite this, Prof Gluckman said he told a media gathering that he believed that putting folic acid in bread was healthy, and giving folic acid supplements in early pregnancy reduced the chances of certain defects. He said scientifically, the right thing to do was to put folic acid in bread, but politically and due to public concerns, government could not ignore the public outcry. He said this was indicative of the fact that the science community had failed to properly communicate to the public on the issue.

Prof Gluckman said that while policymaking appears like a less complex process on paper - from identifying the problem, to policy, to implementation and evaluation - it is in reality more complex, as it is influenced by factors such as pressures from the public, policy analysts, and lobbyists.

Another challenge for science is when scientists collect and present data to service a cause, It is always best when instead of advocating for something, scientists become honest brokers by trying to overcome biases to offer advice appropriately. 


\section{Science informs advice, it does not make policy}

He reminded delegates that there are different audiences for scientific advice, and that the science community tends to focus on offering advice at a national level while at local government, there is also a strong need for advice to oversee crucial aspects like urban planning, water supply, and energy, amongst others.

He concluded that there are five types of science advice: technical, regulatory, deliberate or formal, informal, and advice in emergencies.

Technical advice tends to focus on straightforward specific issues, and informal advice - the kind of advice that most scientists should spend time on - is instant and responsive and incorporates the brainstorming aspect, which is what policymakers need. When it comes to scientific advice, advisors become intimately associated with the decision-making process.

The challenge to science advice can be hubris, where scientists think they know the answer. He said there are several principles to science advice that are critical, and that trust is the most important; he emphasised trust between the politician, policymaker, the media, the public, and the science community.

\subsection{Keynote Speaker: Prof Jos van der Meer}

(President: European Academies Science Advisory Council (EASAC))

Prof Van der Meer gave the background to the recently developed science advisory mechanism in Europe by explaining what EASAC is, what it does, and how it fits into the picture of the new advisory mechanisms. EASAC, which was formed in 2001 , is a coalition of the national academies of science of the member states of the European Union (EU), and includes the panEuropean Academy of Science, the Association of All European 
Academies and the Federation of European Academies of Medicine.

He said that EASAC focuses on producing reports across three streams, which include biosciences, energy and the environment.

\section{How does EASAC connect with the EU?}

Prof Van der Meer said EASAC was very successful in that it was recognised by Prof Anne Glover, the former Chief Scientific Advisor to President José Manuel Barroso of the European Commission. He also said that EASAC had close contact with the Joint Research Centre, as well as regular contact with the European Parliament's Science and Technology (S\&T) Options Assessment Panel.

The science advisory structure changed in 2014 when the swearing in of the EU's new President Jean-Claude Junker was accompanied by pressure from non-governmental organisations (NGOs) to no longer make use of a science advisor. EU Commissioner Carlos Moedas and Director-General Robert-Jan Smits were tasked with coming up with a new science advisory mechanism. He said the Commissioner then developed the science advice mechanism exclusively to deal with science for policy and it comprised three mechanisms:

- a high-level group made up of seven prominent scientists tasked with advising the Commission;

- $\quad$ a supportive office in Brussels capacitated with 20 people;

- $\quad$ an advisory consortium of academy networks.

The manner in which the high-level group operates is that they are connected to the Commissioner for research, science and innovation, both on the demand and supply of high-level scientific advice. The high-level group gets operational support, and is connected to the Commission. 
He introduced the individual members of the panel, whom he said were a dynamic mix of individuals from cross-cutting fields of science. He said the high-level group has only met once to date, and encouraged participants to read the minutes of their meeting.

EASAC is part of a consortium of academy networks that are collectively called Science Advice for Policy by European Academies (SAPEA), along with academies like Academia Europaea (AE), All European Academies (ALLEA), Euro CASE (Academies for technology and engineering) and Federation for Academies of Medicine (FEAM). While the members of the consortium have a wide spectrum of science disciplines, they collectively aim to approach challenges by speaking in one voice, being independent and excellent, having an impact, and connecting with national academies.

Prof Van der Meer explained the governance structure of SAPEA, which he said will comprise five presidents, a coordination team, a science director, a communications officer, five executive directors and five policy officers. He concluded his presentation by giving participants a sense of where the consortium was with its work, and said it has created six work packages - the first one dealing with coordination, and the others dealing with advice, interaction with national academies, quality control, communication, and dissemination and feasibility. 


\subsection{Discussion}

- Question: Can one measure the impact that the science advisor has on politics?

Response from Prof Gluckman: I think it is virtually impossible. As Einstein is alleged to have said, "Not everything that you can measure is important and not everything that is important can be measured". The policy process can be complicated. One of the things you can see is the content of your advice coming out in policy.

- Comment: In the negotiations for the sustainable development goals (SDGs), the need for evidence came to the fore. Diplomats who were doing much of the negotiations trusted science and had science advisors with them.

Response from Prof Gluckman: The impact of data in policymaking is changing the entire policy process itself. It is changing the political process, and it is also creating expectations that cannot necessarily be met.

Response from Prof Van Der Meer: The way EASAC has been doing this is to try and get all the available data that can be trusted and be included in the advice, because it is a process in which you learn by doing and you learn by new data.

- Question: What makes a scientific advisor of value, over and above the scientific committees that governments can turn to for advice?

Response from Prof Gluckman: The scientific advisor is like an interpreter; it is like having a person speaking Spanish and a person speaking Japanese. There needs to be something in between. The culture of science and the culture of policy are very different. Once you get into those environmental and post-normal issues, interpretation is needed in both directions. 
- Question: What is the difference between evidence-informed and evidence-based advice?

Response from Prof Gluckman: The difference is solely because of what policy is all about. A policy is made from so many different things instead of just science alone, and if we say science is evidence-based to a policymaker, I think we are being arrogant and implying that we know the absolute answer. If I say evidence-informed, they are more likely to listen. But we still have to fight for the integrity of the science, and stick to what we know and what we don't know.

- Question: What role can informal advice play in the policy dialogue?

Response from Prof Gluckman: The easiest answer is we don't know yet what the informal circuit is going to be when some mechanism is in place. How often will we be called by either the commissioner, by a member of a high-level group, and so on? We are a bit reluctant in that area because we know our strength is in the medium to long-term solid formal advice. 


\title{
2 Panel Discussion: Topic 1 - Science Advice Ecosystem
}

\author{
Prof Jimmy Volmink - Moderator \\ (Dean of the Faculty of Medicine and Health Sciences, \\ Stellenbosch University)
}

Prof Volmink said the process of giving and receiving science advice is complex as it is influenced by people's beliefs, vested interests, values, ideologies, habits, and by structural, cultural and financial constraints, amongst others. He said the first panel would deal with these complexities and focus on the science advice ecosystem.

\subsection{Dr Flavia Schlegel}

\section{(Assistant Director-General for Natural Sciences, UNESCO)}

Dr Schlegel reminded participants that last year was an important one when it came to multilateral development frameworks: the Sendai Framework for Disaster Risk Reduction, the Action Plan for Finance for Development, the adoption of the 2030 Agenda, Agreement on the 17 SDGs, and the Paris agreement on climate change. She informed participants that all these frameworks are partly built on science, and they depend on sound, knowledgebased, forward planning, implementation and monitoring. Dr Schlegel recalled the SDGs and stated that the solutions to many of these challenges lie in the future. Scientific discoveries provide the foundation and the driving force for social and economic development, but the SDGs cannot be achieved unless science and technology inform policymakers through robust mechanisms of science advice.

The United Nations Educational, Scientific and Cultural Organisation (UNESCO) Science Report towards 2030, published in November 2015, shows that countries that have successfully developed their science, technology and innovation enterprises are economically better off, and better able to overcome the 
global financial meltdown that hit the world in 2008. On the other hand, the UNESCO GO-SPIN as an example of a tool a cluster of databases - to be harnessed in view of achieving quality science advice and monitoring science, technology and innovation (STI) in SDGs.

In her view, science advice is more important than ever, and UNESCO is convinced that sound, independent science advice should enhance the quality of evidence-based policymaking. She told participants that in order to have a good ecosystem whereby science advice can develop, policymakers have to ensure a balanced investment in science, respecting the need for both curiosity and demand-driven research. Funding mechanisms that allow for innovative research should also be part of these funding schemes, and UNESCO advocates countries' investment in research using public and private funding. We must strive for equity participation, especially in promoting the participation of women and young people. Public-private partnerships that can create opportunities for young people must be explored. She concluded that we must also be able to present some successful examples of the science advice mechanism in action.

\subsection{Prof Howard Alper}

\section{(Distinguished Professor, University of Ottawa, Canada)}

Prof Alper shared the Canadian experience in terms of science advice over the past eight years. He said while scientists will have different challenges in their respective regions, he hoped their experience might inspire approaches in other nations.

Prof Alper said the current governance for science advice came from the development of a national innovation agenda, which nations need to do in order to:

- $\quad$ Create an ecosystem that can foster innovation, science and technology, so as to enhance economic advancement and improve societal well-being for all citizens of a nation. 
- $\quad$ Develop national innovation strategies, with strong consensus support from different stakeholders (industry/ academia/governments).

In 2007, the Canadian Prime Minister announced the government's strategy, which was aimed at guiding the country's STI policies, programmes and investments. He told delegates that the strategy was anchored on encouraging firms to invest in science and technology, and embracing innovation (which is the nation's major challenge); building on Canadian excellence in higher education; and developing highly skilled people and increasing demand for their talent. The Canadian strategy was built on three key areas:

- $\quad$ Entrepreneurship.

- Knowledge.

- $\quad$ People (talent).

Prof Alper said the centrepiece comprises the principles contained in the strategy, which include excellence, setting priorities, fostering partnerships and enhancing accountability. In recognition of the need to implement the strategy, the Science, Technology and Innovation Council (STIC) was established, and he was appointed as its Chairman on 13 June 2007. He noted that upon his appointment, the Prime Minister had said that he was there at the service of the Prime Minister's office and the government - where the government would ask for advice, give him timelines, and expect him to deliver recommendations on different issues.

Prof Alper explained that the council was unique in that any minister could ask for advice, which has been a great asset to the nation. He added that the council has 18 members (10 women and eight men), and said it was important to have significant female representation in such councils. He said the council's members are appointed for three-year terms, renewable once. Advice from the council has been requested on numerous issues, including: 
- Clinical research.

- Major science research infrastructure.

- Big science.

- University-industry partnerships.

- Procurement.

- Vanier PhD scholarships.

- Sub-priorities.

Prof Alper outlined the process followed after the first piece of advice was sought. He set up a working group, and they prepared an initial advice piece. This was followed by an eight-page document containing sub-priorities, such as the environment and natural resources and energy, amongst others. This was approved by the cabinet, and it was approved without changes. He said seven years later, the council was asked to provide an update on the priorities, and the council had identified the needs across the highlighted areas. He told delegates that the work of the council is also mandated to produce Canada's State of the Nation reports every two years, benchmarking Canada globally in science, technology, and innovation.

He wrapped up his presentation by quoting an assessment of STIC, in the report by the government of Sweden on the "National Research \& Innovation Council as an Instrument of Innovation Governance" (S Schwaag Serger, E Wise \& E Arnold), who wrote:

"Since its creation in 2007, STIC has established itself as a credible and influential advisory body in STI policy. A key factor to its success appears to have been the combination of providing confidential, demand-driven advice, and producing a highly visible and publicised biennial report on the state of STI. STIC seems to have met a demand in the government, and not least the Prime Minister's Office, firstly, for expert input on key issues affecting STI and, secondly, for transparency and accountability by reporting on "the results of 
Canada's STI performance". Furthermore, the State of the Nation reports have contributed to stimulating a stakeholder-inclusive discussion on STI policy. Critical to STICs success is therefore also the willingness and receptiveness by the government to procure and listen to independent, expert advice, to allow the monitoring and measuring of Canada's innovation performance, and to engage in a public debate on innovation policy."

\subsection{Dr Khotso Mokhele}

(Chancellor, University of the Free State and Advisor to Science and Technology Minister, Naledi Pandor)

Dr Mokhele reminded delegates that Science and Technology Minister, Naledi Pandor, had already given an insight into the country's science advisory system in her speech during the opening ceremony of the IAP conference. He reminded participants that Prof Gluckman had stated in his presentation earlier in the day that there are very few areas in government policy in which evidence, knowledge and science cannot assist.

The success of the science advisory mechanisms depends on the maturity of the relationship between science, the science enterprise, society, and the politics through which society speaks. The Canadian, EU, the United Kingdom (UK) and North American situations are examples of countries where science and the relationship between science and politics have matured over many years. He gave an example using the French academy, which is celebrating 350 years of existence, and contrasted it with the academy from South Africa, which is 20 years old, and the academy from Sudan, which is only seven years old. Given this context, some people believe that science advice mechanisms are wholly importable, while there are those who believe such mechanisms are not exportable. 
Dr Mokhele noted that another weakness in academies and science advice instruments is when they tend to be dominated by natural scientists. There are academies that do not need social scientists and humanity scholars, while some, contrary to what the SDGs require, are still led by people who do not believe that social sciences are science.

He said these are some of the issues that need to be corrected. He ended by quoting Prof Gluckman who had said earlier that no areas of government policy cannot benefit from evidence, knowledge and science.

\subsection{Prof Thomas Zeltner}

(Former World Health Organisation (WHO) Special Envoy and board member of the Swiss Academy of Medical Sciences)

Professor Zeltner's presentation was anchored on five lessons and challenges.

(1) Governments are interested in the future, and therefore scientific advice is about predicting the future, which is one of the biggest challenges. He said the challenge is that scientists are predicting the future in a complex world, and participants must find ways to give advice in the complex world. A second lesson is simulations, and scientists should have strong tools for simulations. He urged the scientific community to work on this, as this is an area of weakness. He reminded delegates that Prof Gluckman had spoken about the importance of urban settings, and said a good future lies in building better urban settlements.

(2) We all live in a global village, which means policies are shaped globally by ministers of foreign affairs. He said every country tries to bring in their own interests, which gives rise to a difficult setting. 
(3) As a scientific advisor, one finds oneself with different forms of advice, from academies to trusted international organisations like the World Health Organisation. Prof Zeltner said there was a debate in Switzerland on whether it was perhaps not wise to have one structure giving advice. He concurred with Prof Gluckman's earlier presentation that it is always better to have multiple advice instruments.

(4) There is a need to invest in the accuracy of advice. Studies show that most of the advice that is given is 'nonsense'. Scientists are good at giving short-term advice, but are not good at offering long-term advice that spans over 10 years.

(5) Professor Zeltner noted what the American Medical Association had said, "you should be talking to your patients like they are 14 years old". This is irrespective of their background. He said simplicity and being down to earth were key factors when giving advice to ministers.

\subsection{Dr Tolu Oni}

(South African Young Academy of Science (SAYAS) CoChair \& Senior Lecturer, University of Cape Town)

In addressing the challenges for science advice ecosystems, Dr Oni said there is a need for interdisciplinarity to be applied. She referred delegates to earlier presentations that showed that the world is existing in a post-normal era, where there is much uncertainty. She also said there is a need for public trust.

Dr Oni showed a map depicting the distribution of young academies across the world. Zooming into Africa, she said young academies were scattered across the continent. She noted that there were 21 national science academies in Africa, of which 18 were attending the IAP conference. 
By contrast, of the 10 young academies in Africa, only two young academies (Egypt and South Africa) were represented at the conference.

Dr Oni asked: What is the significance of young academies in the science advice ecosystem? She noted that young academies:

- $\quad$ Promote relevance and the translation of science for society.

- $\quad$ Focus on interdisciplinarity and science policy.

- Maintain a sustained engagement with society.

- Are not limited to critical and potentially controversial moments.

- $\quad$ Put emphasis on increasing the societal literacy of scientists.

- $\quad$ Contribute to a critically engaged public.

- $\quad$ Pro-actively address gender equity.

- Have a disciplinary representation across the sciences.

Amongst the key issues for science advice today is the fact that public support is crucial to policymakers and scientists. Routine engagement improves societal literacy, and it is critical to build trust on a sustained level as this is important for achieving a social licence. Science advisors should be representative of all of society across gender and age to increase societal credibility.

Dr Oni said science advice should be part of the spectrum of engagement skills needed in scientific education and training. This would contribute towards equipping scientists to grapple with the values, ethics and politics needed to engage with policymakers more effectively, as well as with society.

Including the perspective of young academies makes sense as it would allow for a more active engagement across society. In addition to being trained in the post-normal era, young academies adapt very well and have a dynamic approach to science. They are also in tune with emerging issues of societal 
relevance. She said there are examples of young academies that are currently participating in science advice. She gave examples of SAYAS: members who participate in ASSAfStanding Committees; the Swedish Young Academy, which operates a network for researchers and members of parliament; and the service of the Global Young Academy (GYA) Co-Chair on the UNESCO Science Advisory Board.

In conclusion, Dr Oni said while it was already happening to a limited extent, it was important to systematically include young academies in science advisory structures, as well as provide training for young scientists.

\subsection{Discussion}

- Question: On the issue of ego: how can we change the mindset of veteran scientists who do not recognise social sciences?

Response from Prof Alper: Diversity is the key to science advice, and contributes to wise decision-making. I have chaired a diverse council made up of young and veteran scientists, and I tell them to leave their baggage outside meetings, as they are not in a council to advocate, but to give sound advice.

- Question: During the Ebola outbreak, why did there seem to be an absence of African scientists in the science advisory policy?

Response from Dr Mokhele: Once advice came, it emanated from outside of Africa. The question is, were there science advisory systems in those countries where the outbreak first hit? The nature of the suspicious relationships between science and politics is concerning, and there is a need to find ways to confront this.

- Question: How do scientists engage with society about science in order to make them take up the advice without feeling patronised by complex advice? 
Response from Dr Oni: It is an important question, and it speaks to the point made about maintaining a sustained interaction to create a societal credibility. The young academies are training scientists to look at dissemination beyond their publications, and to take it further, for example, blogging about their work without talking down to the audience.

Response from Dr Alper: Scientists have a responsibility to improve how they communicate to the public. After my council contributed to the Canadian State of the Nation report, council members were trained on how to communicate to a diverse audience. Council members who were parents, for example, were told they should be able to communicate concepts like they did with their teenage children.

Response from Dr Mokhele: Scientists fail to disseminate key messages due to their patronising tone, and they don't find themselves to blame. Politicians would not listen to advice if it was given to them in a patronising manner. Scientists need to cease and desist from using the patronising tone.

- Question: How should an advisor give advice to decision-makers when faced with a scenario where the scientific community holds differing views and cannot seem to reach a consensus?

Response from Dr Schlegel: Be transparent about the state of science, and be transparent that there are conflicting answers. 
3 Panel Discussion:

\section{Topic 2 - Science Advice in Times of Disasters/Emergencies}

\section{Prof Sir Peter Gluckman - Moderator}

(Chief Science Advisor to the Prime Minister of New Zealand and Chair, International Network for Government Science Advice)

\subsection{Prof Oyewale Tomori}

(Former Vice-Chancellor, Redeemer's University \& President, Nigerian Academy of Sciences)

Prof Tomori commenced his presentation by saying that the essence of scientific advice is to prevent pandemics. He said with respect to the Western African Ebola epidemic, there were 28639 cases of Ebola virus diseases and 11316 deaths as at 13 March 2016. He said Ebola kills and dehumanises people. Nigeria was commended for the way it handled Ebola, with 20 cases and eight deaths. Ebola remains a 'Hollywood' sadending story. How do we use advice to avoid a disaster? Advice should be given before the infectious disease spreads so that politicians can use the advice to respond.

Prof Tomori told delegates that science advice should be formulated using evidence derived from analyses of historical and contemporary national and international data. Advice should be used as a preventative measure, as it reduces the adverse effects of the disaster, it guides actions for a quick return to normality after the disaster, and also assists in creating a system for response.

He said science should not stand alone - the totality of the situation must be considered. It is important to implement the One Health concept, and collaborate with other disciplines, working in a multi and interdisciplinary way. 
He posed the question to participants: Does the work of the scientist end with the provision of the advice?

\subsection{Prof Coleen Vogel}

(Distinguished Professor, University of the Witwatersrand, South Africa)

Prof Vogel referred to the El Niño phenomenon, part of the El Niño Southern Oscillation (ENSO) cycle, which links fluctuations in ocean temperatures and the atmosphere in the Pacific Ocean. El Niño is usually linked to drought conditions particularly in the eastern parts of South Africa. Given the complexity of the phenomenon and the complex outcomes, some have termed such phenomena as 'Hell Nino'. Her talk focused on whether South Africa has learnt anything from the 'Hell Ninos' of the past.

In the 1990s, South Africa had a transdisciplinary platform (that exemplified post-normal, mode 2 science engagement) in the science-policy practice arena. This was a time when South Africa was involved in intense democratic transition negotiations. Developed at the same time as the national efforts there was also a platform called the National Consultative Forum on Drought, put together to manage the severe 'Hell Nino' of the time. The forum, which was constituted by a variety of organisations in South Africa across several fields, was funded by the Independent Development Trust. The forum included business, civic society, scientists, government, faithbased groups amongst others with a focus being on trying to address the impacts of the drought at the time and to ensure that rural drought-stricken communities received relief. What emerged from the forum were debates, issues, solutions and science linked to policy. Publications were sent out and these documents gave various viewpoints and started to provide the basis for effective drought risk management. This forum eventually paved the way for legislation on rural development, drought and disaster risk reduction and the rural development programme. 
Fast forward to 2016: Despite the activities of a transdisciplinary forum over 20 years ago the current crisis management approach begs the question - why are we reacting in a crisis management approach? Rather than a reflexive approach, authorities seem to be reacting in a crisis mode and appear to have gone back to a more linear approach of using science to effectively manage a climate challenge such as EI Niño. She said there is no consultative process similar to that of the early 1990s. With the current drought that has hit South Africa, Prof Vogel asked why there is limited engagement and why we seem to be unable to 'learn lessons' from past drought events.

\subsection{Prof Ram Babu Singh}

(Vice-President, IGU and Head, Department of Geography, Delhi School of Economics, University of Delhi Geospatial Technology)

Prof Singh said he would use his presentation to reflect on how his country, India, dealt with their disasters. He told delegates that science advice was needed in a disaster emergency because there is a need for first responders to know about risk patterns, especially in terms of causes and effects. There is also a need to disseminate risk information using geospatial information technology, and a need to promote the application of the science-policy interface.

To effectively manage a disaster, a framework is needed to carry out these duties, including tools and scientific materials, supply management, and recovery, communication, amongst others. He said technology can play a very important role in hotspot identification, as it will promote efficient rescue programmes. He said other components of emergency management include a disaster management force, animal emergency response, occupational safety, public relations, and the media.

Disaster response teams need to identify certain types of equipment and scientific tools, including fire-fighting equipment, lighting and power equipment, individual protective tools, 
mountain rescue equipment, medical first-response kits and equipment for nuclear, biological and chemical emergencies. He highlighted that effective response and communication are needed during an emergency, and components like analysing risk, response capabilities, and estimating the disaster damage are also important.

Scientists have to improve the response capability of the people by having decent networks and equipment to provide relief to communities. A partnership between government, non-governmental organisations, and the private sector was key to managing disasters. Databases for the preparedness for emergency situations are also important, and an on-line inventory of emergency responses helps with a swift response. He said the Indian Disaster Resource Network was a good example of how useful it was in communicating and helping communities with the latest updates during disaster situations. Aerial photographs were also helpful when it comes to the deployment of resources such as vehicles. Mapping the neighbourhood was important for post-response activities.

Prof Singh noted that India's early warning system for cyclones was useful in tracking cyclones via satellites and radars. It also aided in the dissemination of information to the print media, and for warning people of an emergency or impending flood. He gave an example of the 2013 precipitation anomaly Phailin, where emergency response was able to warn and evacuate people on time and save many lives. Prof Singh concluded that there was a need to build an effective science-policy interface during an emergency situation to ensure an effective response.

\subsection{Prof Bernard Slippers}

(Professor in Genetics, University of Pretoria, South Africa)

Prof Slippers said young academies are not yet sufficiently part of this science advice network, and young scientists have a limited role to play during disasters. The important thing at such times is to be connected and be able to connect to trusted and 
experienced networks of science advice, including the voice of young scientists. It is also important to connect with communities, including through social media, such as Facebook and Twitter. Young scientists are the most connected to this community, and the recent example of the power of social networks is South Africa's \#feesmustfall campaign, where students used the hashtag to force government to freeze tuition fee increases for 2016. How do young scientists feel about this role we might give to them?

Prof Slippers noted that across the board, young scientists believe they need to be involved, but most feel they do not have the skills or the platform/opportunity. The Global Young Academy movement is very important to address these issues. These young academies are promoting networks and are launching programmes to address the skills deficit.

Young academies are creating space for regular interdisciplinary, international, and intergenerational dialogue on scientific issues. Young academies are also building mechanisms through which future science leaders can be developed; they are building mechanisms for the systematic identification and development of future science leadership capacity; they are creating platforms for young scientists to get involved in science advice; and young academies are becoming hubs for young scientist organisations and programmes. 


\subsection{Prof Virginia Murray}

(Vice-Chair UNISDR Scientific and Technical Advisory Group (STAG), Public Health Consultant in Global Disaster Risk Reduction, Public Health England, UNISDR Scientific and Technical Advisory Group)

Prof Murray said she would use her talk to unpack the Sendai Framework for Disaster Risk Reduction 2012 - 2030. Disasters cost, hurt and kill but evidence is very thin. Climate change seems to be impacting on us even more. The United Nations (UN) member states have been driving the process to try and take the science community to a stage where we can work more easily. The climate change agreement has been hugely influential, and so are the SDGs.

The Sendai Framework for Disaster Risk Reduction comprises four priorities for action, including understanding disaster risk, strengthening disaster risk governance, investing in risk reduction for resilience, and enhancing disaster preparedness for effective response. Sendai covers all hazards.

She spoke of the need to promote scientific research for disaster risk patterns, disseminate risk information, and promote and support the availability and application of science and technology in decision-making. In summary, the Sendai Framework 2015 - 2030 seeks to implement such systems.

\subsection{Discussion}

- Question: How does one go about changing the mindset of policymakers who have intractable biases?

Response from Prof Murray: The Sendai Framework was written by UN member states: it is their framework, and it is what 187 countries asked for. 
Response from Prof Vogel: If one engages policymakers upfront, you might have less of this intractability as you go on down the line. Honest brokering could work.

- Question: How can scientists get governments to take science advice during disasters seriously if the conduct of scientists is questionable, for example, the reports that 100000 samples left West Africa during the Ebola outbreak?

Response from Prof Tumori: When you take the samples from me without saying what you will use them for, in your own country, it shows dishonesty.

Response from Prof Murray: For that, you need a risk register. In the UK, there was a huge problem. We now have a science advisory system on disasters. Debates happen on the outside in the advisory group to make sure we give the best advice.

- $\quad$ Comment from Prof Onishi: Japan has a disaster risk reduction plan after the tsunami. The Science Council in Japan wanted data from the government but could not get the data from the government. The proposal by scientists was that there should be a very good relationship with government agencies, private companies, and also government itself.

- $\quad$ Question from Prof Onishi: Considering that there are different levels in which decisions are made, who are scientists advising?

Response from Prof Gluckman: Depending on the scale of the emergency, government needs to have a system in place between science and technical advice into the emergency of the appropriate scale.

Response from Prof Tomori: African people, for instance, are not at the same level of development as the other regions. Therefore, scientists should advise according to the needs of our people. 
- Comment: Deciding an emergency case for a politician is very difficult. A decision-maker has to decide in the dark because they don't know what the outcome of the decision will be. Could science not step in at that stage again not to advocate, but to explain to some extent?

Response from Prof Gluckman: That is where science is trying to help: by reducing the risk of uncertainty.

\subsection{Closing Remarks}

Prof Murray: The discussions have been rich. It is really important that scientists get more engaged, and it is critical to have the system work at local and national levels. The Sendai Framework can work well in this regard.

Prof Vogel: It shouldn't just be science and policy. It would be really good for us to keep the frame, not just science for policy.

Prof Slippers: We must leave no scientists behind, and it is time we reflect as a science community on why it is that in times of crisis, scientists see opportunity and not a responsibility. There are systems within the community that perpetuate that, and we need to change that.

Prof Tumori: Solution - advise according to the problem we have. 
4 Panel Discussion:

Topic 3 - Science Advice in the International Arena with a Special Focus on Synthetic Biology

\section{Prof John Hildebrand - Moderator}

(US NAS Foreign Secretary and Regents Professor, University of Arizona)

\subsection{Prof Francisco Gonzalo Bolivar-Zapata}

(Institute of Biotechnology, National Autonomous University of Mexico)

Prof Bolivar-Zapata said that the experience of using synthetic DNA came not long ago. Genetically modified organisms (GMOs) have been developed for different purposes, but over the years, GMOs have been demonised. The use of GMOs is commonly believed to be harmful to humans, which is a myth. Reality and scientific evidence overwhelmingly suggest the opposite. There has been a significant reduction in the use of chemical insecticides that are harmful. There has been no solid evidence to prove that they harm either human or animal health. This is increasingly supported by over 2000 scientific articles supporting the safety of GMOs. There is an extraordinary set of possibilities when it comes to the use of synthetic biology. Scientists must ensure that fear and ignorance without a real solid basis does not delay the use of these technologies.

\subsection{Prof Ernst-Ludwig Winnacker}

(Former Secretary-General, Human Frontier Science Programme)

Synthetic biology can best be defined as the construction of new biological parts, devices and systems, and the re-design of existing natural biological systems for useful purposes. 
There are two types of genome technology that permit biology to become synthetic: genome sequencing and genome editing. Genome editing is a dream for many scientists working in the DNA field, as it is equivalent to making changes while writing a document on the computer. Because of the precision, some of the people in the field who invented this raised concerns that this technology can be used on humans in a way that is inappropriate.

Therefore, a small committee was set up under the leadership of David Baltimore that prepared an agenda for a global summit in this field and which took place in December 2015 in Washington DC. The conference discussed the issues surrounding these new technologies and arrived at several conclusions, which included the following:

- $\quad$ Intensive basic and preclinical research is clearly needed and should proceed, subject to appropriate legal and ethical rules and oversight.

- Many promising and valuable clinical applications of gene editing are directed at altering genetic sequences only in somatic cells (cells whose genomes are not transmitted to the next generation).

- $\quad$ On the clinical use of germline cells, the committee found that there are scientific risks associated with inaccurate editing.

- $\quad$ The international community should strive to establish norms concerning acceptable uses of human germline editing and to harmonise regulations, in order to discourage unacceptable activities while advancing human health and welfare.

\subsection{Prof Rees Kassen}

(Research Chair, University of Ottawa, Canada)

Prof Kassen spoke about do it yourself (DIY) synthetic biology. Synthetic biology is applying engineering principles to biology. What you get is a system where you synthesise a gene to make a product. He spoke about Andrew Pelling, who was recently 
named one of top 20 TED Fellows. Pelling is typical of people who are doing DIY synthetic biology - he is very collaborative. He works with the community around him, and they are innovative and entrepreneurial.

Prof Kassen said the major challenge with science advice is identifying leaders and experts working outside the 'normal' academic community and institutions of research. He said DIY synthetic biology is happening and cannot be stopped.

According to him, it would be good to engage the DIY community through major DIY competitions; establish links with SynBio workspace hubs; support co-development of standards and tools; ensure that scientists can track who is buying what from where; and consider modifying the Cartagena protocol on biosafety to include DNA devices as well as organisms.

\subsection{Prof Keymanthri Moodley}

(Director, Centre for Medical Ethics and Law, Stellenbosch University, South Africa)

Prof Moodley delivered a presentation.

\subsection{Discussion}

- Question: How can societies be protected, given what can be done by modern technology in synthetic biology?

Response from Prof Kassen: First of all, they must recognise this as an issue. The way the Internet worked, you didn't have to redesign communications systems. What the community of DIY is saying is that most of this work is happening in communities. The teaching that is going on is mentorship. My best suggestion is to engage directly with communities. Do not presume these people are not doing any work - they are. They are going to help with self-policing. We have to think about DNA barcodes produced by specific companies, etc. 
- Question: What kind of regulatory systems are in place for synthetic biology, and are they good enough?

Response from Prof Bolivar-Zapata: Legislation doesn't exist yet. The technology is very new. However, legislation for the use of GMOs is present in many countries and should be used to guide legislation for synthetic biology.

- Question: By linking with the hubs in the DIY synthetic biology community, can all parties create an effective code of ethics or behaviour?

Response from Prof Kassen: This is already happening in some communities in the United States and in the United Kingdom. The science academy and the DIY communities have come together to create their own code of conduct that they will abide by. The challenge for this community is that many people are not connected to people in these hubs.

Response from Prof Winnacker: The scientific community and the DIY community have to agree on some code of conduct.

- Question: Is there a cultural possibility that the hackers can real-time connect with regulatory authorities? Is that culturally possible?

Response from Prof Keymanthiri: It is something we need to think about as a regulatory system that needs to catch up. How do we control the Internet, social media, the informal scientific sector: it is a challenge for the 21st century. It is something to which we need to apply our minds because we can foresee a loss of control where people outside of institutions in their garages and in their basements are doing as they please. While there are some that are responsible, there are always those who will use science to the disadvantage of mankind.

Response from Prof Bolivar-Zapata: It is also the other way round. If you remember, in February 1975, the mayor of Cambridge, 
Massachusetts banned the use of recombinant DNA. The danger is if we don't communicate properly on what they can do and what they cannot do.

- $\quad$ Question: Is the cloning of human beings happening?

Response from Prof Bolivar-Zapata: Why would you clone a human being? As far as we all know, it has never been done, but it would be very difficult to do. The United Nations has prohibited human cloning.

\section{WRAP-UP SESSION}

Prof Lai-Meng Looi (IAMP Co-Chair), in wrapping up the day's sessions, said delegates attended the conference because they know they can provide a voice of reason to governments in this complex and troubled world.

The science community has been doing a self-assessment of how it can play its advisory role more effectively. Prof Gluckman said in his presentation that decisions will be evidenceinfluenced more than evidence-based, and decisions will have to be sensitive to local and regional constraints. Delegates deliberated on the science advice ecosystem - various frameworks that provide advice. Participants have considered the skills required in providing advice, and the need to be multidisciplinary. Young academies asked for the need to improve on the societal literacy of scientists. She thanked participants for sharing their thoughts. 


\section{Conference Day Two - 1 March 2016}

6 Panel Discussion:

Topic 4 - Country Readiness for Science Advice

\section{Prof Detlev Ganten - Moderator (IAMP Co-Chair)}

Prof Ganten introduced himself as the Co-Chair of the InterAcademy Medical Panel (IAMP). With effect from 1 March, he will become the Co-Chair of the InterAcademy Partnership for Health. He welcomed all to the conference and recalled that on the previous day much was shared on counselling: who to counsel and what to counsel. The question for this session was whether governments want scientific advice. It appears that some governments do not get the right advice or do not follow the right advice, otherwise the misery and problems we face would not be the way they are. He said that ways must be found to convince those who do not want to listen. The first session will be about that.

\subsection{Dr Orakanoke Phanraksa}

(Co-Chair, Global Young Academy and National S\&T

Development Agency, Thailand)

Dr Phanraksa is a lawyer and she provides legal advice in Thailand. Since being involved in the science academy, she has learnt how to convince policymakers.

She briefly introduced the Global Young Academy network. It was created five years ago, and has 200 members from six continents and 101 alumni. The majority of members are from Europe, followed by Asia and North America. She extended an invitation to other countries to enquire about joining the network. 
She noted that there are 68 males among the 200 members of the Global Young Academy. Normally males are dominant in such organisations, but for the first time the GYA has two female Co-Chairs. They work together and have their meetings in different countries. They have divided themselves into working groups.

Their current project is called the Global State of Young Scientists. The aim of the project is to concentrate on the national constraints of young scientists. This project focuses on students who, when they return home, face constraints from their governments. The project will explore ways of making life better for young scientists.

All disciplines are welcomed in this target group, with the age limit of 40 years to be considered a young scientist. The key indicators for this group are:

- Motivation to enter research.

- $\quad$ Support mechanisms for young scientists.

- $\quad$ Access to career mentoring - Dr Phanraksa noted that she experienced constraints and pressure in her own country, and addressed the issue with her government. The Thai government has picked up on this project and is running a mentoring system for young scientists.

- Gender equality.

- Scientific productivity, excellence, impact and innovation.

- Career paths and obstacles faced.

- $\quad$ Obtaining grant funding.

- International mobility.

- Interdisciplinary.

- $\quad$ Self-perception and effectiveness.

- Motivation research.

Dr Phanraksa gave an overview of how the project and funding has progressed into other countries, and explained that new funding was received for extensive research in Africa. In Thailand under the current government, they tend to leave out 
the middle-income group. With this project, the focus will be on supporting all young scientists who need assistance, under the supervision of the GYA. The government has for the first time established a high-level Science and Technology Institute and formed a government advisory committee, which is another spinoff from this project.

Dr Phanraksa said Thailand is one of the developing countries with a Science Advice Committee, and where advice on policy drafts is supposed to be put into practice, but it is a challenge. She said she looks forward to seeing her government progress in selecting people to work together with global experts in finding good solutions on how science advice can be used in policymaking.

\subsection{Prof Mahouton Norbert Hounkonnou}

(President of Benin National Academy of Sciences)

Prof Hounkonnou noted that he agrees with what has been said about science advice, but he would like to use his presentation to enlarge the topic by introducing some specific aspects. Civil society and the public sector are the reality of science advice to policymakers. However, this reality depends on the culture and education of civil society. Most developed countries seek science advice, but in the developing countries this system still needs to be constructed due to a number of reasons.

Prof Hounkonnou posed four questions:

- Why is science advice important for a developing country?

- What is the objective readiness of a country for science advice?

- $\quad$ Are these conditions satisfied in most countries of the South?

- Why and how can the academies of sciences in our countries contribute towards the construction of the optimal conditions for a country's readiness for science advice? 
Country development globally considers knowledge production and sharing, which requires adequate scientific and technological expertise. Prof Hounkonnou said that a country cannot be developed if it is unable to produce and share knowledge. He noted that there are at least three major conditions for science advice:

- Well-structured and sufficiently empowered institutional framework for science policy.

- $\quad$ Close collaboration between policymakers and the scientific community.

- $\quad$ Scientific culture and level of education of the society.

Prof Hounkonnou described the two general categories that the countries in the South fall into:

- $\quad$ The first category includes the emerging countries like Brazil, China, India, and Korea. These countries have realised the objective conditions for science advice.

- $\quad$ The second category encompasses most African countries, except South Africa, Morocco and Nigeria. In most of these countries, the objective conditions for science advice are still lacking. This is due to the weakness of the scientific community, partly in terms of its disorganisation, poor national research directions, and so on. This can also be attributed to the non-cooperation between science advisors and policymakers.

Prof Hounkonnou said that these are the major challenges in preparing countries for science advice. The facts show that complex problems require multidisciplinary advice for solutions. Therefore, the major challenges for preparing a country for science advice are:

- $\quad$ Discussing information and finding solutions involving science, technology and innovation, and dealing with the real socio-economic development of a country. This is done through appropriate analysis, and by developing systems and using existing models that facilitate learning from experience. 
- $\quad$ Scientific culture and education must be promoted in different countries.

- It is important to bring scientists, policymakers, decisionmakers, civil society and the private sector together.

- $\quad$ Open network knowledge areas need to be built that will involve many forms of learning and problem-solving.

- $\quad$ Bringing together various constituencies to discuss solutions to major questions of development, and to decide on policy recommendations for national, regional or continental organisations.

\subsection{Prof Kurt Lambeck}

\section{(Professor of Geophysics, Australian National University and Director of the Research School of Sciences, Australia)}

Prof Lambeck emphasised the importance of science advice to inform policies. Science advice underpins everything that is done in policy. It is important to governments and policymakers, and to those who influence policymakers. He spoke about his experience after 12 years at the interface of science and policymaking as Vice-President of the Australian Academy of Science, and also as President of the Academy. He realised:

- $\quad$ there is no single approach to science advice;

- $\quad$ there is no simple approach to providing science advice;

- $\quad$ the approach today might not be suitable for tomorrow.

Changes that occur in governments happen on a far faster time scale than what scientists think. He gave an example of how science advice influenced policymaking in his own country, and how many trustworthy relationships were built. That was followed by a revolving door process similar to a post-war experience, where governments changed which in turn changed the ability of the science community to provide advice. There was no time to build up the trust relationships with the new people. This problem is compounded in modern society when civil servants change positions when ministers change. 
There are two groups of people to deal with every time there is a change in government, and there two types of advice that scientists provide:

1. Formal advice - the response to government, bureaucracy or the civil service to address specific issues.

2. Advice that scientists think government should have without a formal request.

The latter is usually the easier one because there is time to anticipate matters that may arise in the future, like therapeutic cloning. Preparation for the underpinning research is done through expertise-based committees and by bringing in the academy's fellowships to broaden the expertise of these committees. Often these issues go beyond pure scientific matters and involving the non-science academies into the discussion is important.

Another type of advice is emergency advice in a crisis where the minister or department needs it for immediate decisionmaking. A rapid approach that relies on the policy division of the academy for support, and people who have time to assist at short notice are needed. This advice is not always as well-founded as one would like it to be, but it works fairly well. Government must be informed that the advice will be given on a very short time frame, and that more time is required for more well-founded advice, as weaknesses could have been overlooked.

He emphasised that the intended target should be kept in mind when giving advice. He cited the example of Australia, where there is a dual system: the Federal Government and the State Government. The focus of the academy is on the Federal Government and the State Government tends to be neglected. He added that it is also important to give scientificbased advice to state and local governments which, in turn, feed back to the higher levels that exist in the Federal and State Governments. Cooperation with regional or discipline-based 
scientific bodies is important in formulating advice. For example, the state-based Royal Societies in some instances can play an important role.

He said the business world needs more attention. In the climate debate, for example, business is usually concerned with the risks associated with advice, not the details of the science itself. They are less concerned about the uncertainties of science as they are about the risks associated with these uncertainties. Scientists tend to focus on the interesting aspects where there are unknowns, and two or three per cent uncertainty and not about the $97 \%$ or $98 \%$ of certainty because that part is usually not central to their decision-making. Without making it clear that there is a solid base of knowledge upon which the experts agree, there is a danger that focusing on the more interesting unknowns, the entire basis of the science is dismissed as being uncertain.

The Australian Academy also focuses on education of the public. The Australian Academy contributes to education by improving the science teaching in primary and secondary schools (the Primary Connections and Science by Doing Programmes), and by providing on-line information of scientific issues of current public interest.

One of the challenges is distinguishing between science advice and lobbying for science. Finding the balance and constantly being aware of getting the right information out without losing the trust of both the public and the government is important.

The Australian Academy is not always equipped to provide the information required. Change happens rapidly in the science and technological world and there is often not enough experience available to provide advice on areas that impact on societal values. Nearly every issue that requires science advice has an element of social impact, whether it is dealing with public health issues, economic issues, or with social welfare. The Australian Academy therefore encourages 
contributions to emerging S\&T areas, and to work closely with the social sciences, humanities and the technological science academies.

If there is trust and a common language, along with an understanding of the respective roles of the science community and politicians it becomes easier to get governments to act on science-based advice. This is a continuing process as a change of government requires the process to start all over again. There is no remedy other than to keep at it and not to give up hope.

\subsection{Dr Margaret Hamburg}

(Former Commissioner, US Food and Drug Administration)

Dr Margaret Hamburg is an MD from Harvard and Cornell University and Commissioner of the New York City Department of Health in 1991. She was also Assistant Secretary for Planning and Evaluation in the US Department for Human Services and Commissioner of the Food and Drug Administration. She has also been nominated as Foreign Secretary of the National Academy of Medicine.

Dr Hamburg has worked on both sides of the equation regarding government readiness for science advice. She has given advice to governments on numerous occasions and has also been on the receiving end of seeking advice from others. As a longstanding member of the Institute of Medicine and the Academy of Medicine, she had to find ways of influencing government to bring important issues to the attention of policymakers, and to try to work together to advance the services of science in society.

The United States was in a unique position as President Lincoln first established a National Academy of Sciences in 1853. It was charged with the mission to provide independent and objective advice to the nation on matters of science and technology, and also to provide science advice whenever called upon by any government department. President Lincoln recognised 
the importance of science advice to advance the state of the nation and increase the competitive advantage of the US in the world.

The National Academy of Medicine was not originally part of that vision, but today it forms an important part of the National Academy in advising on certain issues of health and medicines. It was called the Institute of Medicine until recently when the name was changed to the National Academy of Medicine.

The National Academies of Science, Engineering and Medicine has impacted on the medical and scientific policy world in the US not only regarding policymaking but by playing an important role in science, medicine and public health in communities. They have also played a critical role in advising government on sciences, which is central to the academy's mission and success. The US was well positioned from the very beginning because of the way the academy was created. Their ability to serve effectively and maintain influence and value depended on the principles and processes of government, which in turn gave them credibility, authority and confidence.

The model was developed over many years within the US academies and can offer something of value to other academies around the world to strengthen their approach and organisational processes. There needs to be continual change: updating and modifications in how everyone works together towards matters around science and global matters across borders. There are evolving challenges when governments change and science advice becomes more complex. The foundation of this academy's authority to provide credible science advice that was listened to and acted upon, was critically dependent on the academy's access to expert and unrivalled convening power.

Governments currently face many competing voices and much more scrutiny. Science advice has also become multifaceted. Governments are always looking for easy, quick 
and short-term solutions, rather than long-term problem-solving solutions. Matters of science are intertwined with social values and ideologies, and it is tempting for governments to not make decisions, rather than get in the crossfire. Under pressure and information overload, the desire to latch onto a certain way of thinking about a problem can become very tempting, but it underscores a really pressing need for the credibility of the science advice. The job of government in many ways is harder than ever.

She expressed her confidence in academies. They can become the world leaders but cannot follow old trends or be entrenched in old issues. Academies must learn how to be more responsive in how they do their work. They must find ways to undertake many complicated tasks more quickly. They must be able to hold quick workshops on timely or important issues, or have regular roundtables bringing partners together to discuss evolving issues that need continuing attention in a more active and engaged way. Academies must be willing to be more collaborative in engaging with all the areas of expertise and knowledge needed to address important questions.

Age, geographical representation and diversity are critical as well. The US academies are working hard to expand membership and to reach and involve more volunteer participants to work on problems. In this way, they will ensure that diversity and experience are used to find meaningful solutions. Fellowships will be called upon to bring more disciplines into the work of the academy.

Academies must also be more willing to be open about the work they do and how they do it, as this is really critical. It is important to have public sessions and public input as well. Academies need to adapt to how they serve government and there needs to be ongoing dialogue with academies in different countries. They have different contexts, demands, expectations, and different ways in which they execute their work. 
Most pressing problems are multifaceted, which require crosssector and cross-border collaboration with other academies in finding answers. Government is notoriously bad at working in these cross-cutting ways. Academies are well positioned to help government decision-makers assess these intrinsic complexities, and to help find meaningful strategies that can override bureaucratic silos and barriers to reach out to the various groups that need to be engaged to find solutions.

Science and technology have become intrinsically complex, and it is impossible for a government entity to have the expertise in-house that could solve problems. They need to engage those experts inside and outside of government, and need a safe harbour to explore important issues.

\subsection{Discussion}

- Question: This meeting is about getting all the academies together to form an InterAcademy Partnership, but the Global Young Academies are still somewhat fragmented. How do you collaborate and how do you envisage collaborating with the InterAcademy Partnership?

Response from Dr Phanraksa: Although they are still new, they have working groups providing for young academies. In November 2015, they hosted the second worldwide Young Academy Conference in Stockholm where they divided the academies into working groups to see how they will help the young academies to integrate and partner with other academies. There will be follow-up meetings in Japan next month, followed by another in July. Other colleagues in Africa are running the same meetings. The GYA will serve as the facilitator for the collaboration of the other academies.

- Question: Thank you to the panellists for very impressive presentations. I have a few comments. To Prof Lambeck - You spoke about how to speak to decision-makers and politicians. I will give an example. Twenty years ago this month was the first 
time I walked into the Prime Minister's office to represent the community on a particular issue, and I was given ten minutes. We ended up speaking for an hour and forty minutes on a broad range of issues, including science advice. The Prime Minister said I was the first person that had ever come into the office to address these issues, and immediately it became a personal issue. The Prime Minister's Office told me to tell the university administrators to use a language they understand and to change their vocabulary. To Dr Orakanoke - The toughest part of mentorship is making good choices as to who mentors who. Do you have any comment on this?

Response from Dr Phanraksa: Responding to the comments on the mentoring system, at the GYA not only from the international level but also locally, we need to learn from each other and learn together. I believe that most people from South Africa and other African countries would like to learn how to mentor the next generation and be groomed to become the next leaders. The next workshop will start in Bangkok in June this year.

- Question: I want to understand the Global Academy a bit more because in Nigeria we have a young academy that is mentored by the national academy. They do involve some of the African academies in what they do. How do you get your members? Is it a network of global academies, or do you organise elections of young people all over the world and how did this start?

Response from Dr Phanraksa: It is my plan to introduce the GYA to everyone here. The history of the GYA derives from the first time that young scientists were invited to join the World Economic Forum in China in 2008. They convened and said that we should do something for the next generation. A year later they convened again in Germany, and decided to drive things forward for the global science community. Membership is a five-year term by election, and we send out a call for membership every year around August, with a deadline at the end of September. We select the best young scientists from the 
incoming applications from both developing and developed countries. We meet every year - this year we are still deciding whether we will meet in Turkey or elsewhere. We welcome all applications, but they must meet the criteria of the academy. You must have a degree, and these days we try to attract people from the private sector. In the past, scientists came only from academies, and in reality we should also work together with industry to create that linkage. Finally, those who are with their national young academy will get extra points because they have already been certified by their academy.

- $\quad$ Question and Comment by Dr Moneef Zou'bi: Can academies create new and innovative ways of getting their messages across to politicians by expressing their opinions through economic or monetary terms? I believe that academies have a problem in conveying their messages to politicians because they come from two different worlds: politicians come from economics, political science, law and history, while scientists come from science faculties. Maybe academies should think about bridging the gap at an early stage at university level.

Response from Prof Lambeck: The process that we have developed is to do that through personal contacts: by making scientists available to meet with parliamentarians and encouraging parliamentarians to identify matters that they would like to discuss. In the past, we found developing personal contact with a minister, about an educational programme, for example, can work because in many instances there is no guarantee that the minister sees advice that has been provided to a minister's advisor or offical.

Response from Dr Hamburg: Much of the work they do in medicine is trying to work with agencies and government on the actions to be taken, which is of enormous value. They do this by working closely with government. Public engagement is very important, and academies are not only providing advice to governments but are also providing information and education to the public, making the work of academies credible and accessible. 
- Question: It is much easier to give advice in a proactive manner than to respond to a request from government with advice. I can understand that it is easier because you can spend time on thinking what the problems are. Does that relate to the extent to which government takes up the advice?

- Comment: The delegate asked to share some of the experiences of their specific academy of sciences over the last 20 years. They have experienced an unstable political climate that changes every four years when parliaments change. Since the development of trust is an important element, they found it more effective to work through the federal officers; that is government agencies that provide the drafts for new legislation, or they are consulted by their ministries when it comes to questions that are raised at a political level. By establishing stable contacts with senior officials at these agencies, they found that it is more effective to get their message through in the long term. Often that comes back to the previous remark that often in these federal offices you have scientists who have a university education and a scientific background, who understand their messages and the political climate. They find this very useful and it is bridging the gap in a way. They also transfer their publications to the secretariats and political parties, which has proved to be an effective channel of communication.

- $\quad$ Comment: Professor Lee from Malaysia spoke about young scientists attending the World Science Forum in Budapest, who have not yet met with the GYA. He said that the next World Science Forum will be in Jordan, and urged that a group of young academies and UNESCO visit to scale up the activities of young scientists.

- Question: This topic, country readiness for science advice, is very important and I would like to tell my colleagues and friends here that we at the Chinese Academy of Engineering, and also the Chinese Academy of Science, are ready for science advice. The Chinese government is also ready for science advice from the scientific community. Our two academies 
are going to sponsor and host the IAP, InterAcademy Council (IAC) and IAMP meeting in September, which will be a good opportunity for the scientific communities all over the world to come and share our experience. We would like to welcome you all in Beijing in September.

The delegate asked Dr Margaret Hamburg about her changing role from government to science, and wanted to know if science advice may not be as appropriate as the government officials think?

Response from Dr Hamburg: I will start with the last question. When I served in government, it was very valuable to seek advice from the National Academy of Medicine and the National Academy of Sciences. It was important when it was complex science, when we needed help to dissect what the critical issues were and how to address them. When there was a controversial issue that was too highly charged for us to effectively deal with, then it was good to ask the academies to take it into a safer, more protected environment for thoughtful discussion. We also used the academies occasionally in studies, or workshops that were done as a way of bringing new broader attention to a problem, because in an environment where government is often distrusted, certain messages coming from the academies could have more resonance, meaning and value. We relied on the academies for guidance, help and partnership to address many of the important challenges before us. What was important was that the academies needed to change ways of how they were doing things because we could not wait 18 months to two years for a long, well-documented, valuable study. Sometimes we needed more of an action approach and had to lean on experts to address the issue with us. Sometimes we needed the academy to engage a broader set of players that were experts and that were highly credible. A lot of the work that is done by the Academy of Medicine is initiated by government or government officials in Congress who are experts on the issues. 
Response from Prof Lambeck: On the question of measuring the impacts of the unsolicited reports, you are quite right: they can become navel-gazing exercises. If an issue raised becomes important and action follows from it you cannot claim credit for it. You must just congratulate the government for making the right decision, and it means that you will not really know what the impact of your report has been. On the questions of working directly with government and the agencies, work on both levels. You work with the chief scientist of the country and you work with the broader science community to try to reach consistent advice.

- Comment by Prof Hounkonnou: It is probably easy to give advice, but follow up and the implementation are very important. In this way, I think the major player is a specialised journalist who is well informed and trained on a specific question, which can help with the follow up of advice.

\section{Keynote Speaker:}

\section{Prof Jacqueline McGlade}

(Chief Scientist, United Nations Environment Programme (UNEP))

Prof McGlade gave an overview of the UN and science. The UN tends to be more taken up with statistics and action, and in the middle they concentrate on the millennium development goals and now the SDGs. There has been a huge transition underway within the UN recently, and people are concerned about how they will follow up on the enormous agenda of what to do next and where they want to go. This will require that the entire spectrum of the science of scenario-building, economics, of using remote sensing and so on, be on board. In one way, the UN is very ill-equipped to deal with this huge agenda. They have broken the problem down into small steps or building blocks. These steps will describe what is going into the agenda and how members can become part of the move. 
Lots of information will need to be collected once, and can then be used many times, by citizens, scientists and so forth.

To access this technology, the first challenge is to unlock data or information. One of the first things to do is identify how valuable open data is. Twenty years ago, there were only 40 countries that had open data policies, and now there are over 120, not least of which is the open data policy for Africa. Every country in Africa has signed up. They are not all there in terms of having signed the policy, but they are slowly and gradually delivering data. This is an extraordinary process. More than 100 countries with open platforms are on the way to becoming legislatively robust. There are about two million open statuses that have been opened by governments: as data are reported, they become publicly available. The value is extraordinary, and it is truly impressive.

There are huge technology changes, which brings its own challenges for science as well. Often a lot of technologies are out there for people to use, but many academies in the developing world do not see that the proliferation of these kinds of technologies can accelerate their access to information.

There is a two-way working process at the UN. Peacekeeping is one example of it, where you have to work without Wifi, and then bring things up to date and synchronise it as soon as you are connected. There is a need for big investment in science because of the public interest that thrives on wanting more and more information and technology.

Within this UN setting, they have absorbed this technology change from measurement to big data and innovative platforms on the UN Data Systems Catalogue, which is what builds and pulls together knowledge. An example is the SDG ontology, which enables data collection from one domain to be discovered by other domains, and builds a comprehensive knowledge system so that information can be aligned from one end of the world to the other. Science is very important, but real 
people, scientists, are needed on the ground. They must be authoritative and recognised.

There are environmental perfectionists who sit in academies, and there are also a number of mathematicians, physicists and so on, who provide an enormous amount of insight into how the planet is formed. She also said that language brings an interesting layer both in context and in meaning. In the SDGs there are 23 different meanings of "access to services". The lawyers have come under the discipline of ontology to work through what these 23 different meanings of "access to services" mean and are working hard to find a solution.

Prof McGlade was challenged two years ago by UNEP to come up with a way to take the fundamental science of academia and take cognisance of traditional knowledge, indigenous knowledge and the alternative view of the world that is taken from mother earth. It is important for everyone to understand all the issues and language when putting documents or resolutions together. By a process of intergovernmental invitation and also by nomination, Prof McGlade's office assembled 1200 scientists across various fields and diverse regions. These scientists are engaged in the very best of science and are proactively working in the field and bringing other young scientists on board. They must cover the six languages, and have now inserted into every assessment a three-stage peer review of engaging with government, the sciences, and civil society.

The organisation is now trying to move to other data sources, which are widely available and have no cost factors. A decision was taken that all documents published for download would not have a pay barrier any longer. Ways will be explored of making arrangements with authors, publishing houses and others to make articles and documents more accessible and cheaper. The interest now is on how to improve quality and avoid plagiarism. The organisation has also become the clearing house for a lot of material and information. After a year on this project, the UN managed to cut plagiarism down to $5 \%$. 
The UN has been known to produce the reports for countries that do not have enough civil servants, and those smaller countries rely on the UN for documents and reports to provide information to their governments. A huge transition was made when all documents were transferred to digital products and e-books, so that governments and policymakers can have the information available wherever they are. Citations and references are also more readily available. More products will be coming out soon, such as the Global Agenda and the big GO6. The Regional to the National to the Sub-national with their assessments will also be released soon. In May 2016, regional assessments that are connected to global drivers will be released for the first time. Scientists, governments and civil society have been put together in their various settings with the aim of finding out what the key priorities in their regions are, because regional priorities are very different. When planning for global assessments takes place, it is important to reflect these differences.

A platform called Unit Live, which was launched successfully and with 193 countries reporting combines all this. This platform will integrate all the data and is able to connect with other platforms and update data immediately with some of their partners. Analysis is updated every three days, so information can be accessed on a day-to-day basis.

At the other extreme, some states have the data stations but are not connected to the UN. The challenge is always that they cannot afford a quarter of a million dollars on an air monitoring systems portal. An inexpensive box has been invented at only \$1 500 with high accuracy and hybrid networks, and does the same job as the air monitoring portal. This means that a monitoring system can be run at a local level.

Within a space of three or four months since it has been released, over 40 countries are willing to participate in the monitoring at their own cost. This is a great turnaround and provides a sense of empowerment. This will not only bring the information to 
the public, but will also improve life inside cities, which is core to the SDGs. There has been a huge transition in cities, and local communities want to participate and understand the environment.

Prof McGlade said they have a duty to countries who want to increase their capacity for the statistic offices. South Africa and Africa needs to do more, and are challenged to do the aggregation. There is a huge amount of work to be done in getting definitions for smaller countries where data and statistics are not available. There are also huge challenges for putting policies in place. The data forms are in the process of being tuned into dashboards that can be used and understood more easily. They are also working with other countries like Afghanistan to obtain data from old papenwork and libraries so that it can be made available for research on earthquakes and soil maps, etc.

The technology can be used with social media and on all the various social media platforms and is available in all the UN languages. Ministers want daily intelligence to help with emergency decisions and to get to grips with what is happening. The reason for building this system was to achieve an understanding of where the different controversies and arguments of scientific criticisms were coming from.

Precipitation is changing, climate change is inevitable, and innovative ways must be found for future planning to avoid compromised sustainability to the demands in the food chain and water supply. This will involve the US Geological Services and many other institutions. Planning of this nature requires enormous science capacity to produce all the information and projections. IAP is a really important player in trying to mobilise expertise across the world. No one country has all the information in their back pocket, so it is really important for academies to facilitate the network across the world. 
The second Environment Assembly, which is like the General Assembly, will be held in May 2016. It has full membership and it reports directly to the General Assembly. It is not just UNEP; it also includes WHO, the United Nations Development Programme (UNDP), UNESCO, and anybody who wants to say anything about the environment.

Prof McGlade explained that at some of the UN meetings, ministers feel exposed and have requested a Science Policy Forum before the meeting where they will rehearse the arguments and understand the issues beforehand, and will be able to listen to what civil society is saying, etc. An open science policy forum, where there will be launches of big assessments coming from all the various platforms has been arranged. It is a place where science and policy will meet and policies that will be binding will be put into texts. This is where they must make sure that they have the right science informing the right policy because these policies will be around for a very long time and this delegation cannot afford to make mistakes. The very best minds are needed. All resolutions will be public and published on the website under UNEP.

\subsection{Discussion}

- Question from Prof Hassan (Moderator): What is your process of selection of the scientists for your panel and do you see any room for engaging with academies for this process?

Response from Prof McGlade: When the governments and civil society said that they wanted much more engagement, every government was invited to nominate, and every IAP member was invited to nominate. Many countries put forward their best scientists and they went through their own academy. I did write to the IAP and did not get a reply, but all the academies are extremely well represented in the 1200 . Comparing this to the Intergovernmental Panel on Climate Change (IPCC), where there are nearly 4000 scientists who are specialised in many cases; many of them are also in the 1200 and there is a bit of a crossover on climate. There is still an open invitation, and I 
would strongly suggest that you nominate your best applicant and send it to me or write to me at my address on the UNEP website.

- Question from Prof Hassan (Moderator): If I remember correctly, UNEP recommended that every country around the world should invest at least 2\% of their GDP in Green Initiatives and Green Economy. Is UNEP monitoring this?

Response from Prof McGlade: We have been accompanied down this road by the Green Grows platform, which is a huge investment process. Out of 60 countries, there is positive growth in excess of $2 \%$ in about 30 countries. There are still 130 countries to go, and what we see is that the language is wrong. The Green Economy language is not the language of many parts of the world, and it is more about transformation and sustainability. In Africa, energy is by far the most enabling thing to put in place and that is where I see the focus is now: regional enabling conditions.

- Question: When you are coming up with suggestions and then a conclusion, how do you follow it up?

- Question from Dr Moneef Zou'bi: I think that you are a very brave scientist to be standing in front of 90 plus academy representatives to talk about academies of sciences and promoting SDGs. My problem is that in the past, a lot of effort was made by the academies to interpret what was required of the academic community to help achieve these goals (MDGs and SDGs). I am glad to see that some effort is made by the UN to reach out to the community of academies. I don't think it is too late, although I think that at the point of drafting the SDGs, it would have been helpful to carve a role for science academies. I understand that the role of science is crosscutting, as Prof Hassan often reminds me, but still it will save a lot of time if such missions are assigned to science academies to help the UN system and humanity in achieving its goals. 
- Question: I am very impressed, and the presentation was fantastic. It is very useful for us but I always find there is a gap between education and reality. We understand the bare minimum, and it looks nice and we can contribute to this kind of work. But once you put this into reality, you need a person who can interpret this nice result into the absent problem.

Response from Prof McGlade: UNEP only consists of 700 people, so it is a tiny piece of the UN. We work tremendously well with all the parts of the UN and with other agencies on the ground through partnerships. One of our demands is to be more and more on the ground and having more access. We will never have infinite resources, so your point about having interpreters or translators is absolutely essential, whether it is because of language or knowledge or the texture of knowledge. In the science setting, we have Geo fellows with a direct task to translate. I agree with you, we need to work more with interpretations and with different communities.

I am not a brave soul. I can pretty much recite to you, off by heart, every target and every indicator because of the work I have been doing. There are going to be about 200-odd targets and indicators that we are going to be looking at next week. Tiers 1, 2 and 3: Tier 1 is an international standard, Tier $2-$ we have a standard but not many countries reporting on it, and Tier 3 - we have no standard and we do not have anybody reporting on it but we think it is a good idea. We don't expect to have the answers tomorrow but in two or three years' time and there will definitely be a requirement.

- $\quad$ Question from Prof Hanaki: This was a very impressive presentation that was truly optimistic. However, I cannot resist a key question. In reality, real-time reporting is a challenge. In your work, how can you overcome this real-time reporting and monitoring?

Response from Prof McGlade: One of my jobs before I came to the UN was to run the European Environment Agency, and I 
had exactly the same challenge. At that time, I used the sledge hammer: it was a lead table and a blank map. A blank map is a useful device - you put it in the report, you put it up on the website, and it is blank for the countries to insert their data. Within 24 hours they have their data sent because the public just see it and it is so obvious. However, we have to be more subtle than that. What I feel now is that we are developing a very different trust relationship with member states. That is why open access data are so critical. We are trying to say to citizens that it is part of your basic rights to know what kind of environment you are living in. We want you to have a healthy environment where your food will not be contaminated. So we want you to have a public consciousness of what is around you. It makes it very difficult if countries do not report, and in many instances a lot of people are now monitoring the environment. It is even harder to hide the facts. Our job at the UN is to look at legitimacy, to look at empowerment, and to check and encourage and put in place the right systems to use.

- $\quad$ Question: The MDGs have just finished, and you will find that some countries only made one or two targets. Now we are given the 17 goals to meet: how are we going to meet that?

- Question: $17 \times 4$ is a lot of categories. The question is: is the system going to produce something that is helpful in prioritising? We do have something called Co-data. In the UN system, it has been a mistake all along to consider the science community as a stakeholder. It is not a stakeholder, it is not a constituency, but it is a tool.

- Question: Many thanks for an in-depth and comprehensive presentation. You mentioned world water quality assessment: is it part of the assessment of quality?

Response from Prof McGlade: There is one message: despite massive investment in infrastructure around water, we see that it has not led to improvements of water quality in many countries. With MDGs and SDGs in science, I am trying so hard 
to get every UN agency or entity to have alongside each chief statistician a chief scientist. Every part of the UN needs something like that to make it systemic and to really build it up. We don't have science within the kind of framework of where we are and this will make science more visible. I hope that we can build around all the core issues whatever it is, whether or not it is captured by indicators and is almost secondary to do. We know where we want to go with the SDG setting. Can we get the MDGs linked to the SDGs, which are more in tune with what government is all about than the MDGs? So we are on a good value proposition?

- Comment from Prof Virginia Murray: I am just delighted by the achievements that you have made. I would like to remind everybody that the SDGs do include disaster risk reduction goals, and we are working through a partnership.

8 Panel Discussion:

Topic 5 - Interplay between Science Advice, Politics and the Media

\section{Prof Robbert Dijkgraaf - Moderator (Co-Chair, IAC)}

Prof Dijkgraaf briefly outlined the importance of communication and mentioned the fast evolution of communication instruments, such as cell phones and the Internet, and the way that all these communication elements impact policy and science advice.

\subsection{Ms Linda Nordling}

(Science Journalist, Research Africa)

Ms Nordling said that it is quite a tall order to be representing the media at a gathering like this. She comes from print media and cannot speak from the TV and radio point of view. 
All her writings are about Africa, the UK and Europe, and she does not know much about the rest of the world.

- $\quad$ The media has changed a lot, and this has been

facilitated by the development of technology, such as online media and social media. News can now reach you faster wherever you are. The print media has been under a lot of pressure financially as budgets and newsrooms are shrinking. There is juniorisation of the newsrooms, which means there are younger people covering complex stories now, although experience does count.

- $\quad$ There has been a proliferation in science journalism globally. In terms of training, there are now numerous courses available in science journalism. One of the problems is that there are not many jobs for science journalists. Most of these people end up in communication jobs as science communicators at universities. In South Africa, there is a particular problem in that very few newspapers take science content at all. There is also huge confusion: government wants to train science journalists but there are no jobs for them. On the one hand, you have a lot of scientists who want to get their work out through the media, and on the other hand, newspapers don't want the information.

\subsection{Mr David Mair}

\section{(Head of Unit, European Commission)}

Mr Mair works for an organisation called the Joint Research Centre, which is a scientific body inside a policy body at the European Commission. It gives them a perspective on how to link science to policy, and the media is a crucial part of this connection.

Mr Mair said that until now this has been a binary discussion, where everybody has only been talking about the world of science and policy. This relationship was actually a triangle of science, policy and society, where policymakers have to be 
extremely open about what is going on in society and the media must make sure that this happens. If you want to be effective in policymaking, then it is important to make sure that what you are writing is picked up by the media in a powerful way. It is also important that the kind of advice that we are giving is open to the public domain and open to scrutiny. The information is open, can be contested, and discussed more widely. We need to avoid developing new technologies or new innovations that make politicians happy without taking into account the views of society. We must make sure that we work all three sides of this triangle.

Scientists must think about why they want to engage with the media. In the same way that you need to separate science from policy, and policy from science, it must also be clear why you need the media. Are you talking to the media to promote yourself and your work, or are you talking to the media because you want to have an impact on policy? Those are very different discussions and it is important to keep them separate.

\subsection{Prof Charles Weijer}

(Canada Research Chair in Bioethics, Western University, Canada)

Prof Weijer noted that a lot of the conversations at this conference have been about science and government. We need a broader view that takes the interaction between science and society seriously. Informed citizens are crucial to the functioning of any society and democracy. A more practical way of engaging citizens is in effecting social change. It is the citizens themselves who will rally together, lobby governments and engage in activism. So it is very important to engage with society.

Prof Weijer presented three points that highlighted how to change the interface between science and society:

- $\quad$ Engagement - This is something that speaks to scientists and various publics like a two-way street. People might disagree with science, and one of the reasons could 
be ignorance, but there are other important issues that need to be taken seriously, such as competing values, cultural beliefs and religious beliefs. We need to engage and discuss the values and beliefs relevant to science.

- $\quad$ There is a special need for humanists and social scientists. They can help to understand the beliefs that motivate people, and then practically inform the messaging of science. Maybe more importantly, humanists and social scientists can help to engage the public in a more respectful way. They can also help with how social ends can and should be informed by sciences.

- $\quad$ The engagement with the public can be useful in informing science itself. Much of science advice is about risk. By understanding public values, science can be more responsive to public concerns.

\subsection{Prof Sameh Soror}

(Professor of Biochemistry and Molecular Biology, University of Helwan, Egypt and immediate past Co-Chair of GYA)

Prof Soror said that the relationship between science and the media reflects that there is a gap in communication. However, both media and science need each other. It is a triangle, and to mix this with the society effectively, it is necessary for science to mix with the media. The relationship between media and science can be described like the relationship between water and oil. When you mix oil and water, you can get two different outcomes. When you mix up the proportions incorrectly, you will get a disaster but if you mix the combination correctly, then you will have a very good, strong and efficient product. The key point here is, how can we achieve the latter, and how can we get the right combination for the right product? 


\subsection{Prof Bruce Alberts}

(Chancellor's Leadership Chair in Biochemistry and Biophysics for Science and Education, University of California)

Prof Alberts has been focusing on creating better receptors in the United States for scientific ways of thinking through science education for children. He has been working with other academies, particularly in Europe, to see whether they could get organisations to help children think like scientists, starting at the age of five by doing simple scientific activities in school, learning to argue and how to look for scientific evidence, and respecting other people's views. The last fact was important so that they will understand that respect for all and everything in life is required to become a respected citizen in society.

He said that there was a need to create citizens who can distinguish evidence from fact, and look for evidence and logic in making their personal decisions. Based on his 12 years' experience at the US National Academies, which publishes about 200 reports a year, he noted that the key challenge was to gets the policy advice used rather than getting it in the news headlines or in the Washington Post.

Societies are divided into different culture groups relating to each other. It is as if an anthropologist is needed to connect science and society, to show what their values and cultures are about. Science fails to recognise that other groups have very different ways of thinking, and don't immediately connect to what the sciences say or what the scientific community says. It is therefore important to think about how to include other groups in activities, including the media, which can become valuable resources for what they are doing. 


\subsection{Discussion}

- $\quad$ Prof Dijkgraaf (Moderator): I understand the critical role that journalists have to play. What is at stake in building media journalists who are able to do all kinds of heavy lifting and what can the science community do from their perspective?

Response from Ms Nordling: There are many things they can do, but it can also be quite difficult as a journalist. When scientists and academies approach journalists with their reports or their findings, they see journalists as the gatekeepers. Because the traditional media is quite constrained, it might be a bit of a bottleneck to try and squeeze through. With the proliferation of science journalist training, you see that science for development or media is funded by donors. In this way, your story is much easier to get out there because it is not vetted by an editor of a newspaper; it is pushed by an agenda, usually funded by the donor. There are now a group of journalists who have only written for this type of media institution, and they are not encouraged to question what they are told.

- $\quad$ Prof Dijkgraaf (Moderator): David, would you like to comment on the validation of information?

Response from Mr Mair: There is a quote from a socio-biologist, which sets out the paradigm of both journalism and anthropology. It says: "We are drowning in information while starving for wisdom. The world henceforth will be run by synthesisers, people able to put together the right information at the right time". That is where there is a community of interest between journalists and scientific authorities in particular. The problem is not that we lack the knowledge, but there is an abundance of knowledge that science and politicians are unable to cope with. There needs to be a coalition between journalists who are experts at filtering and sorting the news, but they need to understand what is credible, what is authoritative, which results should be ignored. You can see the results in nutrition, where things go horribly wrong. 
- $\quad$ Prof Dijkgraaf (Moderator): Is there any particular instance where there was anything that was mentioned that was right, and also when it was able to reach the world of policy?

Response from Mr Mair: One has to look at the IPCC in the recent climate change negotiations. Despite the obvious difficulties, there was some action in the way things were presented. Our organisation ran a model to calculate what would be the temperature effect of all the promises of all the countries as they went in, and that got picked up and the story that ran after that was "if you ran all the promises of all the countries and if you go into Paris, this does not look like enough".

Prof Dijkgraaf (Moderator): Does this speak to your point of the two-way traffic?

Response by Prof Weijer: People tend to surround themselves with information that they agree with, and that has made it harder to reach people. Journalism is maybe part of how we reach that group. When people insulate themselves by participating in that group with like-minded individuals, they become harder to reach. The solution here should be broader than the media, and it requires engagement with people on a level playing field, where you actually talk to them about what they are interested in, what they believe. Do this in a respectful way so that there is no upfront discrediting.

- $\quad$ Prof Dijkgraaf (Moderator): Prof Alberts, in terms of your role as a publisher, do we need journalists as guardians of scientific practices?

Response from Prof Alberts: I learnt a lot from that five-year experience, and one thing I learnt was how poorly scientists communicate. As a biologist, I could not understand half of what they were trying to communicate, and they worked very hard on that but then most of the abstracts had to be rewritten by editors. I feel that it stems from their training. Scientists think what they know, everyone else knows, and everything that is in 
your head is not shared by others. The positive transition during my time with the media was when the young journalists started a social media group and started sharing science information via the group, which was a tremendous help to all.

- $\quad$ Prof Dijkgraaf (Moderator): What are some of the ideas that surfaced in your discussions with colleagues at the young academy, and why do you see the opportunities drowning in this sea of information?

Response from Prof Soror: The first thing was to develop the skills of science communication. Right now there is interest in training undergraduates in communication, but not science communication to improve their skills in a scientific way. Scientists need to learn how to communicate science in a simple way and in a clear way to get across the impact of what they are doing. The media wants something that is attractive and needs some flavours that may change the communication of the information completely, and the credibility of science will increase. Capacity building is needed early to learn how to communicate science properly. Young people do not have time for long drawn-out communications in newspapers or TV or other classical things; short precise sentences make more impact on young people today. We have to learn how to communicate with them and how to transform our scientific language to a language that they understand.

Prof Dijkgraaf (Moderator): In social media, you can at least put a link to a scientific report, which is good.

[The discussion was then opened to the floor.]

- $\quad$ Prof Gluckman: Countries with science media centres have seen improved science communication through the mass media. I think the five that exist are Japan, Britain, New Zealand, Canada and Australia, and they are usually funded by ministries in relationship with science academies. They employ professional scientific journalists who dissect the information out 
of the scientific literature into lay language, which the ordinary media people can comprehend without understanding the science.

The second thing they do is they write good things with commentary and critique on controversial issues, so that the media gets a balanced view on complex issues. The one in New Zealand is funded by the government through the academy, and they have proved to be the most valuable way of getting the uninformed media more accurate stories of the mass of scientific information. This should be looked at more broadly.

Response from Ms Nordling: There is another advantage of such science media centres: as a scientist, you can talk to these people in your own language and get something across quickly and don't have to go through a writing process, which makes it ready to respond to calls for information from the media centre. The media centre in Australia works well.

- $\quad$ Comment from Prof David Harel: I agree that most scientists have difficulty communicating and that it is a serious problem. My experience with writing expository articles or books has been good, but with a couple of exceptions, interviews with the press have been disastrous because the last word was in the hands of the journalist. Sometimes journalists can make a big mess and take things out of context. Thinking scientifically and trying to put the right kind of words at the level of the public is very difficult to do. I believe scientists fail more at this than they succeed. What is Ms Nordling's response from a journalist's perspective speaking to a scientist where there has to be more sharing on the final outcome before it goes to publication?

- Comment: Ms Nordling does not have to answer for all the mistakes that have happened to everyone from the media. The question is about the audience, because there is an assumption that scientists need to engage with the audience, but there are different kinds of audiences, and there are not many scientist jobs and the reason for that is demand. How many people present read science journalism that is not in 
their field? If they want more science journalism, then demand needs to be shown for it by scientists.

- $\quad$ Prof Dijkgraaf (Moderator): Is there one recommendation that you would like to formulate at this time that you picked out of this gathering?

Response from Prof Alberts: The US academies have done a three-year study on how to analyse all the myths around GM foods. They are hoping to communicate this effectively by using various communication skills and platforms of media.

Response from Prof Soror: The audience does not want to hear all the detailed analysis of our reports and findings. They just want short, clear and affirmative messages.

Response from Prof Weijer: Until we are able to engage people with the values of what they live, we will not make any progress with our communication of what we want them to know. So, we have to frame our message in terms of the values of daily living.

Response from Mr Mair: We need to become serious about Twitter. In the world of policymaking, it has an extraordinary reach. Policymakers and advisors watch what is being said on Twitter about them, they follow the debate. It is a very important driver of the policy debate, and perhaps the preeminent one at the moment. If you want to know who the successful journalists are at the moment, then they say find out on Twitter. In terms of journalism and policymaking, Twitter is a preeminent tool. A major failure of this conference is that there is no hashtag for this conference. Each academy needs its own Twitter account where it publishes its work, and even fellows should do that. All your events need a hashtag so that people can start tweeting it and it can trend. One needs to share your life's work in 140 characters to be able to tweet. It is that first interesting introduction that gets people interested, and that will be useful for influencing policy. 
Prof Dijkgraaf (Moderator): That's the homework for everybody.

Ms Linda Nordling: Everybody present needs to think about how they measure the impact of their communication efforts. For a lot of people it ends with the published story. The big question is who reads your work and did it make a difference? It is a much harder thing to measure, but much more important to look at. You get a better idea of who is reading, who is following, and who cares.

Prof Dijkgraaf thanked the panel and the audience for a lively debate.

\section{PLENARY DISCUSSION, CONCLUSIONS, RECOMMENDATIONS}

Prof Daya Reddy (President of ASSAf and IAC Co-Chair) welcomed everyone back to the last session of the conference, and said that this is the session where they officially take stock. Prof Reddy outlined the proceedings for the last session, which both he and Prof Jörg Hacker (President of the German National Academy of Sciences in Leopoldina and IAC Co-Chair) would facilitate.

9.1 Day 1 Wrap-up

(Prof Daya Reddy, President of ASSAf and IAC Co-Chair)

During the opening ceremony, Dr Heide Hackman gave a presentation on Science International, the series of meetings organised by the International Council for Science (ICSU), the International Social Science Council and the IAP. The first activity was a meeting that took place in December 2015 and the next step is to have academy scientists, unions, universities, governments and everybody to sign up to the Accord. Out of that emerged a parallel capacity building initiative for data scientists in Africa. 
The address by Minister Naledi Pandor, Minister of Science and Technology of South Africa, raised a few key points. She confirmed a strong relationship between the Department of Science and Technology and ASSAf, and also mentioned the independence of the Academy. She made a point of talking about research and development in South Africa, and stated her aim of spending $1.5 \%$ of GDP (at the moment it is less than 1\%). She had some strong words towards the end of her presentation about gender equity, in particular in science academies.

On Day 1, keynote speaker Prof Sir Peter Gluckman made the following points:

- $\quad$ Science and policy are fundamentally different cultures.

- $\quad$ Policymakers need to weigh other factors besides science.

- $\quad$ Scientists need to make their findings accessible to policymakers.

- $\quad$ The need to avoid hubris and build trust: there is much that we don't know and we need to be honest about that.

Policymaking is not a linear and neat - it is messy.

- $\quad$ The need to differentiate between formal and informal science advice.

- $\quad$ Aspiring to be an honest broker as opposed to being engaged in advocacy during the course of providing science advice.

The next presentation was by Prof Jos van der Meer, who spoke about the new European mechanism for peer science advice for policies by academies, and about a two-step process that makes provision for rapid response and a longer term response that may take well in excess of a year. In the discussion that followed, a few questions arose:

- $\quad$ First, how do we measure the impact of the advice that we provide? One response was that we could measure its success by being asked repeatedly for advice.

- $\quad$ Second, all policies have risk but risk is perceived in different ways in different communities. 
During the discussion, there was also a comment about the boundaries between scientists, policymakers and society.

The first panel considered the Science Advice Ecosystem, and was moderated by Prof Jimmy Volmink (Dean of Stellenbosch University):

- Information was provided by the International Network for Government Science Advice (INGSA), ICSU, and UNESCO, who are developing principles of science advice. It was indicated that there should be a role for engagement by the IAP.

- $\quad$ The importance of supporting the advancement of women in science, and young scientists, was emphasised as well.

- $\quad$ There were comments about the low profile of the social sciences, which really needed to be addressed.

- $\quad$ Training for science advice and reward/incentives.

- $\quad$ Scientists have the responsibility to try to understand the society they are engaging with.

The discussion:

- $\quad$ Developing countries with new science cultures, even those with committed science advocates, can become frustrated if they try to approach the matter in the way you would in the developed world.

- $\quad$ Communication - use clear language and be able to explain to a lay person.

- $\quad$ There was debate and some disagreement around the example of explaining science to adults as if they were teenagers of 14 years old.

The second panel looked at Science Advice in Times of Disaster and Emergencies, and was moderated by Prof Sir Peter Gluckman (Chief Science Advisor to the Prime Minister of New Zealand and Chair, International Network for Government Science Advice):

- Here again there was a need to build trust and have open communication channels with the public.

- $\quad$ The need to have locally relevant advice in disaster situations. 
- $\quad$ There was an example of a multi-forum of stakeholders by the communities that had a real impact, but the model has not been sustained.

- $\quad$ Science and technology, for example GIS, can help predictions and early warning systems.

- $\quad$ Science has a role to play in informing communities in how to be prepared for and how to react to disasters and emergencies.

- $\quad$ Young scientists certainly can and should play a role.

- $\quad$ The Sendai Framework for Disaster Risk Reduction, which was recently adopted, is a strong and excellent model of science for policy in this particular context.

The discussion:

- $\quad$ The need for the availability of and accessibility to big data, and to stimulate debate and not adopt one way of giving answers.

- $\quad$ To engage with the situation outside when you are confronted with emergencies would improve the response to emergencies.

- $\quad$ The need to curb opportunistic new science funds essentially piggy-backing onto emergencies.

- $\quad$ The importance of having post-disaster reviews of the accuracy of the advice that would have been received.

- Is there an opportunity for the IAP and the member academies to become involved in the disaster risk process and partnerships?

The third panel discussed Science Advice on Synthetic Biology and was moderated by Prof John Hildebrand (US NAS Foreign Secretary and Regents Professor, University of Arizona):

- $\quad$ Science is moving really fast, particularly in synthetic biology, and the regulations are not keeping up.

- $\quad$ Synthetic biology, GMOs, terminology, and what each of these mean in the minds of the public and policymakers:

o many of the synthetic biologists work outside of academia, so it is not always easy to achieve responsible, ethical research; 
- the public has in some places reacted negatively to GMOs.

o now that we have learnt those lessons, can we avoid the same with what emerges from synthetic biology?

- $\quad$ Need to go beyond organisms to other DNA devices.

At this point, the floor was opened to comments and questions.

- $\quad$ Prof Gluckman: The only point that I would make in relation to my own talk is to give much more to the understanding of what post-normal science is, explaining to scientists that the relationship between science, policy and society is crucial for successful science advice. It must form the complete triangle before informing policy.

- $\quad$ Comment: Some of the points that were raised are to expand our view and to not just have a binary view of science policy but also to include the practice community and the social learning that we can encourage.

- $\quad$ Prof Detlev Ganten: In the discussion on crises or forthcoming crises, and academies making recommendations - once the recommendations are made, the crisis starts, and WHO or any other organisation gets a thrashing for whatever they do, whether they follow the recommendations or not. Follow the discussions and keep the academies within the play and instead come to the rescue of those who had to take the decisions.

- Comment: One issue that is not explicit is the issue of the popularisation of science. Many people think of academies as a company of old men. In the American Mathematics Society, they have a publication called, "What is happening in the Mathematical Sciences these days". I think that if we have at least $50 \%$ of us determine that we will communicate what we do intelligently to the public, it will affect the whole world. What I want to suggest is that all the academies present here should go back and think in what direction we can contribute, and 
get many of our specialists to explain this in simple language to the majority of people.

\subsection{Day 2 Wrap-up}

(Prof Jörg Hacker, President of the German National Academy of Sciences, Leopoldina and IAC Co-Chair)

The fourth panel considered Country Readiness for Science Advice and was moderated by Prof Detlev Ganten (IAMP Co-Chair):

- $\quad$ Thailand was taken as an example and Thailand was shown to be a very ambitious country:

O it aims for a high income by 2026;

- it has a high level STI panel;

- science plays an important role.

- $\quad$ The impact of science advice depends on the level of development in a country and in many African countries the advice framework was minimal.

- $\quad$ Discussion on what percentage of the country's income should be invested into science and technology - in Europe they have 2.5\%, other countries have more, but in some less.

- $\quad$ Academies are normally the vehicles for science advice.

- $\quad$ Advice provided in a short time frame can be limited.

- US academies provide advice, and have reached into policymaking and practice in the US and other countries.

- $\quad$ US academies were established in the 19th Century to give advice to politicians.

- $\quad$ Need to advise and engage stakeholders, including the public, to address conflicts of interest.

- The public is important together with media and politics.

The discussion:

- $\quad$ The need to find a way to speak directly to the minister, to have a shortcut to politicians. 
- $\quad$ Much of the work done at academies is with departments and agencies.

- $\quad$ To work closely with government to scope out the work of the academy.

- $\quad$ The divide between scientists and policymakers often starts at the university level. Can scientists work with undergraduates to bridge the gap? Provide education to the public and policymakers, which will lead to receptiveness in governments.

Keynote speaker Prof Jacqueline McGlade made the following points during her presentation:

- Web intelligence can provide governments and others with up-to-date information.

- $\quad$ Big data can be provided, including social feeds.

- $\quad$ Small countries rely on this service for picking up information.

- $\quad$ UNEP has engaged 1200 scientists into its communities.

- $\quad$ Each assessment goes through a 3-tier peer review.

- A large amount of open data is made available by over 100 governments.

- It can be analysed and reanalysed - it is important to make use of the data.

- $\quad$ Million Voices, citizens and scientists want to get involved in the SDGs, especially via social media.

- $\quad$ The academic community can help at local level and at regional level, as well as with the UN assembly and major groups.

- $\quad$ Need more representation in the UN groups.

The discussion:

- How do the science academies help the UN achieve the SDGs?

- $\quad$ Best scientists should feed into the reports and make the reports more credible.

- Many national academies have experts in UNEP.

- More needed and the call for experts is open. 
- $\quad$ Developing trust with member states to submit data.

- $\quad$ Science community is not a UN stakeholder, it is a tool.

- $\quad$ All the UN organisations should have a Chief Statistician and Chief Scientist.

- $\quad$ The aim is to identify and answer cross-cutting SDG questions.

The fifth panel examined the Interplay between Science Advice, Politics and the Media, and was moderated by Prof Robbert Dijkgraaf:

- New technologies all the time - there is competition for print media.

- Juniorisation of newsrooms.

- Information from the research institutions must be made available to the public for open discussion.

- $\quad$ Think about why we communicate - to give advice or lobby or promote and advertise our findings in the research fields.

- $\quad$ Special role for social scientists in better engaging and informing the public.

- $\quad$ To educate, reason and debate from the age of five.

- $\quad$ The model of AAAS fellows, who can act as a gobetween for government and other agencies, such as science and policy communities.

- $\quad$ Proliferation of publications as a new outlet for young scientists and journalists.

- Have a super abundance of knowledge, and the need for journalists to filter and scientists to provide the credibility.

- $\quad$ Scientists need training to avoid assumptions.

- $\quad$ The need to develop concise reports like short videos.

- $\quad$ Countries with science media centres have improved science.

- $\quad$ Public consultation, especially on contentious issues, can effectively feed back into policy processes.

- Academies should reach out across national borders to bridge political divides. 
- $\quad$ The importance for the public to add a local flavour to breaking new stories.

- $\quad$ Hardly use social media for evidence of data bank conspiracies.

- Get input from politicians on what they want from scientists and how they want it.

\section{Final thoughts:}

- $\quad$ The audience wants short clear messages.

- $\quad$ Clarify the role of the academies.

- $\quad$ Debate subjects like GMOs.

- Engage with groups for scientific advice in a meaningful fashion.

- Values, and get serious about Twitter.

- Challenge to academies on how to measure impact of stories.

\subsection{Questions and Comments}

- $\quad$ Comment: Thank you very much for an excellent summary of what we did over the last few days. I know that this conference was about science advice to governments but it is important to find ways of how the private sector or businesses can play a role in what we do and contribute towards the economy.

Response from Prof Hacker: Thank you, it is important not to ignore the private sector. In the production of knowledge in industrialised countries, two-thirds comes from the private sector and only one-third comes from the state sector. On the other hand, one has to avoid influence in our work at academies.

- $\quad$ Comment: Thank you for capturing most of the points that were raised. I think that it will be useful to add the element of capacity building in the domain of science advice.

Response from Prof Hacker: Yes, in our academies we have a limited power in capacity building, but you are right in that capacity building plays a role in many of our reports. 


\section{- $\quad$ Cross-cutting issues were listed by Prof Daya Reddy:}

- $\quad$ Avoid hubris - science does not have all the answers.

Be an honest broker and be an advisor of trust.

- $\quad$ Avoid confusion between science for policy and policy for science - this is what we have been discussing over the last two days, being in the business of science for policy.

- $\quad$ Need to include women to a greater extent than is the case. There was a report on women in the academies that was released.

- $\quad$ Do not forget the social sciences. Everything we do has an element of the social in it and we must not forget to include the social sciences.

- $\quad$ Ensure that we include young scientists to a greater degree. We are not doing too badly with our engagement of the young academy but there is definitely more to do.

- $\quad$ The question about what to do when rapid responses are required while maintaining that level of rigour that we regard as indispensable or satisfactory.

- $\quad$ How do we as a community go about ensuring that society is better understood by the scientific community, and that society has a better understanding of science?

- Communication is the absolute key.

- $\quad$ Comment from Prof Rees Kassen (University of Ottawa): I would like to re-emphasise and expand on the issue of young scientists. I want to push this community to recognise that they are not just young scientists. It is actually about intergenerational issues across the entire spectrum and including the career path of individuals. The GYAs are now producing cohorts of alumni that are not quite yet at that senior academy level, and yet have the experience of GYA. I also encourage you to think of these other communities that are outside the realm of classic and traditional research because they are going to be the ones that will be really innovating in a big way in the next five to 10 years. 
- Comment: It is important to review the science for policy contents, and to include science advice for policy and society.

- $\quad$ Comment: The way I would put it is that when you are giving science for policy advice, don't include requests for money or support for science because then your whole report or advice will be suspicious. Always take out any request that would make the report look self-serving. For your science advice to be taken seriously you must not have a document that appears to be self-serving.

- Comment: Mostly when people come to science for advice, they usually come like the drunk to the lamp post - more for support than for illumination. This teaches us that scientists have to learn how to talk to power and how to get it across.

- Comment from Prof Coleen Vogel (University of the Witwatersrand): On the point about engaging young scientists, I would like to add that it is also about enabling young scientists. I would like to ask academies if they can start discussions and conversations at universities around enabling environments for young academics who might want to get into post-normal science.

\subsection{Closing: Prof Daya Reddy and Prof Jörg Hacker}

Prof Reddy thanked everyone for their comments, and said the presentations will be on the IAP website and the proceedings of the conference will be published. The summary presented by Prof Hacker and Prof Reddy, together with the subsequent discussion, will be revised and synthesised into a set of comments, conclusions and recommendations in the conference proceedings.

Prof Reddy said there were two Twitter accounts running for the conference, contrary to what was said earlier. One was \#iapartnership and the other was \#assaf, and some conference delegates have been tweeting and retweeting. 
He said the problem was that they did not publicise the Twitter accounts adequately.

As Prof Hassan mentioned the day before, it was the biggest ever IAP conference: in excess of 70 academies were represented with around 110 academy members. There was also attendance from observers and regional networks, so it has been an excellent turnout.

He thanked individuals and groups, starting with the Conference Committee who did an excellent job. He thanked the IAP Conference Co-Chairs and Committee members. Prof Reddy thanked Prof Roseanne Diab and her team, the technicians, scribes and the writing team who collated the summary.

Last, he listed the names of the Committee Co-Chairs, IAP Committee members and Committee members who could not attend.

\section{Committee Co-Chairs:}

Prof Jörg Hacker

Prof Daya Reddy

\section{IAP Conference Committee Members:}

Prof Peter Gluckman

Prof Lai-Meng Looi

Dr Jeremy McNeil
Prof John Hildebrand

Prof Roseanne Diab

Prof Sameh Sorror

\section{Committee Members who could not attend:}

Dr Eva Alisic

Prof Hernan Chaimovich

Dr Ann Glover

Prof Hacker thanked the conference delegates, and complimented the host, ASSAf, for selecting an attractive venue. He thanked Prof Daya Reddy for his impact and contribution, and closed the conference. 


\section{PARTICIPANT LIST}

\section{Mr Wael Abdelaziz}

Assistant to the Director

Academy of Scientific Research and Technology (ASRT)

\section{Prof Ahmet Cevat Acar}

President

Turkish Academy of Sciences

Mr Christian Acemah

Executive Secretary

Uganda National Academy of Science

\section{Prof Emeritus Byung Joon Ahn}

President

National Academy of Sciences

\section{Prof Mohammed Ait-Kadi}

Member

Hassan II Academy of Sciences and Technology

\section{Prof Bruce Alberts}

Chancellor's Leadership Chair

University of California

\section{Dr Trevor Alleyne}

\section{President}

Caribbean Academy of Sciences

\section{Prof Howard Alper}

Distinguished Professor

University of Ottawa

\section{Mr Thomas Arrison}

Executive Director

Inter-Academy Council

\section{Prof Juan Asenjo}

\section{President}

Chilean Academy of Sciences 


\section{Dr Thomas Auf der Heyde}

Deputy Director-General:

Research Development and Support

Department of Science and Technology

\section{Dr Marcello Barcinski}

Full Member

Brazilian Academy of Sciences

\section{Prof Francisco Gonzalo Bolivar-Zapata}

Chair of the Biotechnology Committee Mexican Academy of Sciences

\section{Dr John Boright}

Foreign Secretary

National Academies of Sciences

\section{Dr Siyavuya Bulani}

Senior Liaison Officer

Academy of Science of South Africa

\section{Prof Salvator Bushati}

Chair: Selection of Natural and Technical Sciences

Academy of Sciences of Albania

\section{Dr Claudia Canales}

Project Manager

Smart Villages

\section{Dr Mlungisi Cele}

Acting Chief Executive Officer

National Advisory Council on Innovation

\section{Prof Dato Lee Yee Cheong}

Chair

Global Council of the IAP Science Education Programme

\section{Prof Chin Ha Chung}

Member

National Academy of Sciences 


\section{Prof Michael Clegg}

Co-Chair

Inter-American Network of Academies of Science

\section{Prof Hoosen Coovadia}

Director

Maternal Adolescent and Health

\section{Ms Bernadette Daries}

Scribe

\section{Dr Darlene Mliller}

Director

O HOLY COW Consultancy

\section{Adriana Ivonne De la Cruz Molina}

Inter-American Network of Academies of Sciences

\section{Prof Roseanne Diab}

Executive Officer Pretoria

Academy of Science of South Africa

\section{Dr Christiane Diehl}

Executive Director

European Academies' Science Advisory Council

\section{Prof Robbert Dijkgraaf}

Director and Leon Levy Professor

Institute for Advanced Study, Princeton University

\section{Mr Daan Du Toit}

Deputy Director-General: International Cooperation and Resources

Department of Science and Technology

\section{Momir Durovic}

President

Montenegrin Academy of Sciences and Arts

\section{Dr Mohamed El-Faham}

Science Advisor

Academy of Scientific Research and Technology 


\section{E Prof Dan Mirceanescu}

Titular Member

Academy of Medical Sciences of Romania

\section{Prof Folayan Esan}

IAMP Executive Council Member

Nigerian Academy of Sciences

\section{Ms Kai Feng}

Director

Chinese Academy of Sciences

\section{Prof Masresha Fetene}

Executive Director

Ethiopian Academy of Sciences

\section{Dr Enrique Forero}

President

Colombian Academy of Exact, Physical and Natural Sciences

\section{Dr Gary Gabriels}

University of Cape Town

\section{Prof Rodolfo Gambini}

President

National Academy of Sciences of Uruguay

\section{Prof Detlev Ganten}

President

IAMP

\section{Prof Sir Peter Gluckman}

Chief Science Advisor

Office of Prime Minister's Science Advisor

\section{Dr Monwabisi Bevan Goqwana}

Chairperson: Science and Technology Portfolio

Parliament of South Africa

\section{Ms Anna-Maria Gramatté}

Project Assistant

German National Academy of Sciences, Leopoldina 


\section{Prof George Griffin}

Foreign Secretary

Academy of Medical Sciences

\section{Prof Robert Guiguemde}

President

National Academy of Sciences of Burkina Faso

\section{Prof Jörg Hacker}

President

German National Academy of Sciences, Leopoldina

Dr Heide Hackmann

Executive Director

ICSU

\section{Dr Margaret Hamburg}

Foreign Secretary

US National Academy of Medicine

\section{Prof Keisuke Hanaki}

Vice-President

Science Council of Japan

\section{Prof Göran Hansson}

Secretary-General

Royal Swedish Academy of Sciences

\section{Prof David Harel}

Vice-President

Israel Academy of Sciences and Humanities

\section{Prof Mohamed Hassan}

\section{President}

Sudan National Academy of Sciences

\section{Prof Brian Heap}

Scientific Advisor

Smart Villages 


\section{Prof John Hildebrand}

Foreign Secretary

US National Academy of Sciences

\section{Dr John Holmes}

Project Co-Leader

Smart Villages

\section{Dr Manfred Horn}

Board Member

National Academy of Sciences of Peru

\section{Prof Mahouton Norbert Hounkonnou}

President

Benin National Academy of Sciences

Dr Jorge Huete-Perez

Vice-President

Academy of Sciences of Nicaragua

Dr Bernie Jones

Project Co-Leader

Smart Villages

\section{Prof Sergio de Jesús Jorge Pastrana}

Foreign Secretary

Academia de Ciencias de Cuba

\section{Ms Phyllis Kalele}

Liaison Officer

Academy of Science of South Africa

\section{Mr Jincheng Kang}

Director-General

Chinese Academy of Engineering

\section{Ms Muthoni Elizabeth Kareithi}

Assistant

IAMP/IAP Project 


\section{Prof Rees Kassen}

Research Chair

GYA/University of Ottawa

\section{Prof Imad Khatib}

Secretary General

Palestine Academy for Science and Technology

\section{Prof Dr Khalid Mahmood Khan}

Secretary-General

Network of Academies of Sciences in OIC Countries

\section{Mr Sang-cheol Kim}

Administrator International Cooperation Team

Korean Academy of Science and Technology

\section{Prof Yoo Hang Kim}

Executive Director

Association of Academies and Societies of Sciences in Asia

\section{Dr Zaid Kimmie}

Council for Scientific and Industrial Research

\section{Dr Marina Koch-Krumrei}

Head of International Relations

German National Academy of Sciences, Leopoldina

\section{Prof Aderemi Kuku}

President

African Academy of Sciences

\section{Prof Vijaya Kumar}

President

National Academy of Sciences Sri Lanka

\section{Ms Joanna Lacey}

Senior Project Assistant

IAP

\section{Prof Krishan Lal}

President

Association of Academies and Societies of Sciences in Asia 


\section{Prof Kurt Lambeck}

Australian Academy of Science

Past President

\section{Dr Mario Lanza Santamaria}

Executive Secretary

National Academy of Sciences of Honduras

\section{Prof Maryse Lassonde}

President

Royal Society of Canada

\section{Prof Myung Chul Lee}

President

Korean Academy of Science and Technology

\section{Mr Edward Lempinen}

Public International Officer

The World Academy of Sciences

\section{Prof Dominique Richard Lenoble}

Academie de Medicine France

\section{Prof Jinghai Li}

Vice-President

Chinese Academy of Sciences

\section{Prof Depei Liu}

Former Vice-President

Chinese Academy of Engineering

\section{Prof Modesto Antonio Cruz Lluberes}

Coordinating Committee for International Affairs

Academia de la Republica Dominicana

\section{Prof Lai-Meng Looi}

Academician

IAMP-Academy of Sciences Malaysia 


\section{Ms Catherine Luckin}

Foreign Secretary

Academy of Medical Sciences

\section{Mr David Mair}

Head of Unit

European Commission

Ms Constance Manyeli

Junior Liaison Officer

Academy of Science of South Africa

\section{Dr Xola Mati}

Chief Operations Officer

Academy of Science of South Africa

\section{Dr Yousuf Maudarbocus}

President

Mauritius Academy of Science \& Technology

Dr Julie Maxton

Executive Director

Royal Society United Kingdom

\section{Mr Kholani Mbiza}

Junior Liaison Officer

Academy of Science of South Africa

\section{Prof Jacqueline McGlade}

Chief Scientist

United Nations Environment Programme

\section{Dr Peter McGrath}

IAP/IAMP Coordinator

\section{Prof Jeremy McNeil}

Foreign Secretary

Royal Society Canada

\section{Prof Jai Pal Mittal}

Vice-President

Indian National Science Academy 


\section{Dr Shadrack Moephuli}

Chief Executive Officer

Agricultural Research Council

\section{Dr Alok Kumar Moitra}

Executive Director

Indian National Science Academy

\section{Dr Khotso Mokhele}

Department of Science and Technology, Chancellor University of Free State, and Science and Advisor to the Minister of Science and Technology

\section{Prof Keymanthri Moodley}

Director

Stellenbosch University

\section{Dr Lindiwe Msengana-Ndlela}

Department of Science and Technology Advisor to the Minister South Africa

\section{Prof Voster Muchenje}

Co-Chair

South African Young Academy of Science

\section{Mr Martin Mulcahy}

Minister of Science and Technology

Department of Science and Technology Special Advisor to the

\section{Prof Virginia Murray}

Consultant in Global Disaster Risk Reduction Imperial College and King's College

\section{Prof Christopher Mutambirwa}

\section{President}

Zimbabwe Academy of Sciences

\section{Mr Anthony Muyepa}

Director-General

National Commission for Science and Technology 


\section{Prof Esther Mwaikambo}

President

Tanzania Academy of Sciences

Dr Isayvani Naicker

International Resources

Department of Science and Technology Chief Director:

\section{Dr Asifa Nanyaro}

Executive Director

Tanzania Academy of Sciences

\section{Dr Jorge Alberto Neira}

National Academy of Medicine Argentina

Ms Linda Nordling

Science Journalist

Research Africa

\section{Prof Joseph Obua}

Fellow

Uganda National Academy of Sciences

\section{Dr Oladoyin Odubanjo}

Executive Secretary

Nigerian Academy of Science

\section{Ms Jackie Olang}

Programmes Director

Network of African Science Academies

\section{Dr Tolullah Oni}

Co-Chair

South African Young Academy of Science

\section{Prof Takashi Onishi}

President

Science Council of Japan

Dr Padilla Carmencita

Academician

National Academy of Science and Technology 


\section{Ms Naledi Pandor}

Minister

Department of Science and Technology

\section{Prof Mohamed lqbal Parker}

Council Member

Academy of Science of South Africa

\section{Mr Imraan Patel}

Deputy Director-General

Department of Science and Technology

\section{Dr Roger Pfister}

Head of International Cooperation

Swiss Academies of Arts and Sciences

\section{Dr Orakanoke Phanraksa}

Co-Chair

Global Young Academy

\section{Ms Josephine Philemon}

Scribe

\section{Dr Gansen Pillay}

Deputy Chief Executive Officer

National Research Foundation

\section{Prof Sir Martyn Poliakoff}

Foreign Secretary

Royal Society United Kingdom

\section{Mr Bob Pullen}

President

International Council of Academies of Engineering and

Technological Sciences

\section{Dr Molapo Qhobela}

Chief Executive Officer

National Research Foundation 


\section{Prof Daya Reddy}

President

Academy of Science of South Africa

\section{Prof Duger Regdel}

Senior Vice-President

Mongolian Academy of Sciences

\section{Mr Hongtao Ren}

Division Director

Chinese Academy of Engineering

Dr Mario Lanza Santamaria

Executive Secretary

National Academy of Sciences of Honduras

\section{Prof Akilagpa Sawyerr}

President

Ghana Academy of Arts and Sciences

\section{Dr Marcos Schevenstuhl}

Programme Director

Brazilian Academy of Sciences

\section{Dr Flavia Schlegel}

Assistant Director-General

UNESCO

\section{Prof Otmar Schober}

Delegate

Union of the German Academies of Sciences and Humanities IAP and IAMP

\section{Ms Patricia Scholtz}

Communication Manager

Academy of Science of South Africa

\section{Prof Ole Mathias Sejersted}

President

Norwegian Academy of Science and Letters 


\section{Dr Ismail Serageldin}

Director

Academy of Scientific Research and Technology

\section{Prof Antonio Sgamellotti}

Fellow

Accademia Nazionale dei Lincei

Prof Mohammad Reza Shams Ardekani

Secretary

Academy of Sciences of IR Iran

Prof Zabta Khan Shinwari

Secretary-General

Pakistan Academy of Sciences

\section{Prof Ram Babu Singh}

Head and Coordinator-UGC SAP DRS III University of Delhi

\section{Prof Ivo Slaus}

Honorary President

World Academy of Art and Science

\section{Prof Bernard Slippers}

Former GYA Co-Chair

University of Pretoria

\section{Prof Himladevi Soodyall}

General Secretary

Academy of Science of South Africa

\section{Prof Sameh Soror}

Former GYA Co-Chair

Helwan University

\section{Prof Crain Soudien}

Chief Executive Officer

Human Sciences Research Council 


\section{Mr Maphosa Stanley}

Liaison Manager

Academy of Science of South Africa

\section{Prof Suad Sulaiman}

Financial Officer

Sudanese National Academy of Sciences

\section{Mr Kosuke Suzuki}

Director of International Affairs

Science Council of Japan

\section{Prof Volker Ter Meulen}

Co-Chair

IAP

\section{Prof Jennifer Thomson}

Chair

Organisation for Woman in Science for the Developing World, South Africa National Chapter

\section{Dr Päivi Tikka}

Secretary-General

Council of Finnish Academies

\section{Prof Oyewale Tomori}

President

Nigerian Academy of Science

\section{Prof Nelson Torto}

President

Botswana Academy of Sciences

\section{Mr Ntambudzeni Tshiswaise}

Liaison Intern

Academy of Science of South Africa

\section{Prof Jaime Urrutia Fucugauchi}

President

Mexican Academy of Sciences 


\section{Prof Alain-Jacques Valleron}

Member

Academie des Sciences de France

\section{Prof Jos van der Meer}

President

European Academies Science Advisory Council

\section{Prof Krista Varantola}

Board Member

Council of Finnish Academies

\section{Ms Susan Veldsman}

Director: Scholarly Publishing

Academy of Science of South Africa

\section{Ms Renate Venier}

National Liaison Officer

Academy of Science of South Africa

\section{Prof Coleen Vogel}

BMW Chair of Sustainability

University of the Witwatersrand

\section{Prof Jimmy Volmink}

Executive Committee Member

Academy of Science of South Africa

\section{Ms Henriette Wagener}

Communication Officer

Academy of Science of South Africa

\section{Mr Zhenyu Wang}

Director

Chinese Academy of Sciences

\section{Prof Charles Weijer}

Research Chair

Rotman Institute of Philosophy 


\section{Ms Sarah Wild}

Journalist

Mail and Guardian

\section{Prof James Robert Wilsdon}

Director of Impact and Engagement

University of Sheffield

\section{Prof Ernst-Ludwig Winnacker}

Member

German National Academy of Sciences, Leopoldina

Prof Kavwanga Egbert Sikazwe Yambayamba

President

Zambia Academy of Sciences

\section{Prof Ahmet Nuri Yurdusev}

Vice-President

Turkish Academy of Sciences

\section{Dr Rapela Zaman}

Director of International Affairs

Royal Society United Kingdom

\section{Prof Lev Zelenyy}

Vice-President

Russian Academy of Sciences

\section{Prof Thomas Zeltner}

Honorary Member

Swiss Academy of Medical Sciences

Dr Moneef Zou'bi

Director-General

Islamic World Academy of Sciences 


2016

Proceedings of the InterAcademy

Partnership (IAP) Conference on

\section{Science Advice}

\section{Academy of Science of South Africa (ASSAf)}

Academy of Science of South Africa

Academy of Science of South Africa, (ASSAf), (2016). Proceedings of the InterAcademy

Partnership (IAP) Conference on Science Advice. [Online] Available at: DOI http://dx.doi.org/10.17159/assaf.2016/00 http://hdl.handle.net/20.500.11911/62

Downloaded from ASSAf Research Repository, Academy of Science of South Africa (ASSAf) 